\title{
DESIGNING CREDIT RISK MANAGEMENT PROCESS IN COMPANIES
}

\author{
DOI: $10.17261 /$ Pressacademia.2020.1330 \\ JEFA- V.7-ISS.4-2020(9)-p.392-408
}

\section{Selda Eke ${ }^{1}$, Ozlem Toprak ${ }^{2}$}

${ }^{1}$ Bahcesehir University, Department of Business, Besiktas Campus, Istanbul, Turkey. seldaeke@yahoo.com, ORCID: 0000-0003-4162-3549

${ }^{2}$ Whirlpool EMEA, Milan, Italy.

Ozlem-toprak@hotmail.com, ORCID: 0000-0003-3228-4063

\begin{tabular}{l} 
Date Received: November 9, $2020 \quad$ Date Accepted: December 24, 2020 \\
\hline To cite this document \\
Eke, S., Toprak, O., (2020). Designing credit risk management process in companies. Journal of Economics, Finance and Accounting (JEFA), \\
V.7(4), p.392-408. \\
Permanent link to this document: http://doi.org/10.17261/Pressacademia.2020.1330 \\
Copyright: Published by PressAcademia and limited licensed re-use rights only. \\
\hline
\end{tabular}

\section{ABSTRACT}

Purpose- The purpose of this study is to show that for a healthy free cash flow, the credit risk is a key pillar for companies and is managed through a process that includes several steps.

Methodology- With a reference to risk management process in general, steps of credit risk management have been been designed. In each step, key credit risk management activities have been mentioned.

Findings- Credit risk management process includes steps starting from risk identification to monitoring of the risk. It is comprised of risk identification and risk analysis activities in scope of Know Your Customer (KYC) principle to assess the buyer's credit worthiness. The appropriate risk management strategies to mitigate risk are also determined after the assessment has been made. Monitoring is the review of the whole process to have the necessary improvements. The entire process has a vital role to decide whether credit sales will be sustained or not and if yes under which credit conditions.

Conclusion- As the world trade grows, trade credit becomes a substantial competition tool for the suppliers. Credit risk appears to become the main cause of the financial loss faced by the suppliers in their credit sales. The credit risk must be managed effectively for the sustainability of world trade activities.

Keywords: Risk management, trade credit, credit risk, credit risk management process, credit risk assessment.

JEL Codes: G32, F65, G23, G22, F10

\section{ŞiRKETLERDE KREDI RISK YÖNETIM SÜRECININ KURGULANMASI}

\section{ÖZET}

Amaç- Bu makalenin amacı, șirketlerde saglıklı bir nakit akışı icin, kredi riskinin önemli bir yapı taşı olduğunu ve çeșitli adımları olan bir süreçte yönetildiğini göstermektir.

Yöntem - Risk yönetim sürecinin genel işleyişi referans alınarak, kredi riski yönetim süreci adımlar şeklinde kurgulanmıştır. Her bir adımda temel kredi riski yönetim faaliyetlerinden bahsedilmiştir.

Bulgular - Kredi riski yönetim süreci, riskin belirlenmesinden başlayarak riskin izlenmesine kadar olan adımları içerir. Kredi değerliliğinin belirlenmesine yönelik "Müşterini Tanı (KYC)" prensibi kapsamında yapılması gereken risk belirleme ve risk analizi çalışmalarını kapsar. Değerlendirme sonuçlarına göre, riskin etkilerini azaltmak üzere risk yönetim stratejileri belirlenir. İzleme tüm sürecin gözden geçirilmesi yoluyla iyileştirmelerin yapılmasına yöneliktir. Kredili satış faaliyetlerinin sürdürülme kararında ve kredi koşullarının belirlenmesinde sürecin tümü önemli bir rol oynar

Sonuç - Dünya ticareti büyüdükçe, kredili satışlar tedarikçiler için önemli bir rekabet aracı olmaktadır. Kredi riski, tedarikçilerin kredili satış faaliyetleri sonucunda finansal zararla karşılaşmasına sebep olan önemli bir risktir. Tüm dünyada ticari faaliyetlerin kesintisiz bir şekilde sürdürülebilmesi kredi riskinin etkin bir şekilde yönetilmesi ile mümkündür.

Anahtar Kelimeler: Risk yönetimi, kredili satış, kredi riski, kredi riski yönetim süreci, kredi riskinin değerlendirilmesi JEL Kodları: G32, F65, G23, G22, F10 


\section{GiRiş}

Finansal kriz döneminde ivme kaybeden küresel mal ve hizmet ihracatı, Covid-19 pandemisi ile ciddi şekilde yara almıştır. Küresel ticaretin daralması ile küresel GSYiH'da düşüş gerçekleşmiştir. İ̧̧ yerleri kapanmış, şirketler üretim yapmak için hammadde temin edemez duruma düşmüşler ve üretimlerini durdurmuşlardır. Arz tarafındaki daralma tedarik zincirinin her halkasını olumsuz yönde etkilemiş bazı mallarda pazarda oluşan talep karşılanamaz hale gelmiş, bazı mallara yönelik talepte de bir daralma sözkonusu olmuştur. Bu daralmanın etkisiyle, zincirin en alt halkasından en üst halkasına doğru satınalma talebinde düşüş gözlemlenmiştir. Üretimlerin durması ve satışların azalmasıyla, şirketler tedarikçilere ve diğer alacaklılara olan borçlarını ödeyemez hale gelmişlerdir. Küresel ölçekte, tahsilatlarda gecikmeler baş göstermiş ve tüm tedarik zincirinde likidite sıkışıklığı meydana gelmiştir. Bazı şirketler ticari faaliyetlerini sürdürebilmek için tedarikçilerine vade uzatım talepleri ile gelmişlerdir. Tedarikçiler de ticaretlerini sürdürebilmek için uzatım taleplerini kabul etmek durumunda kalmışlardır. Finansal kuruluşların 2008-2009 finansal kriz döneminde de olduğu gibi yeni kredi riskine girme konusundaki çekimser tutumları, ticaretin finansmanında şirketler-arası kredilendirmenin önemini bu dönem bir kez daha ortaya koymuştur. Bununla birlikte, şirket iflaslarındaki artış beklentisi ve zincirleme iflasların yaşanabileceği korkusu şirketleri karşılaşabilecekleri kredi riskini yönetmek konusunda daha temkinli olmaya yöneltmektedir. Şirketler kredili çalışma kararının verilmesi öncesinde doğru bir risk değerlendirme sistemi kurmak durumundadırlar. Kredi riskinin önlenmesine yönelik değerlendirmenin sağlıklı yapılabilmesi için iç ve dış kaynaklardan bilgi almanın önemi gün geçtikçe artmaktadır. Kredi riskine girilen müşterilerde ise tahsilatın zamanında yapılmasına yönelik izleme faaliyeti son derece önemli hale gelmiştir. Mevcut tahsilat yöntemlerinin gözden geçirilmesi ve etkin bir tahsilat yönetimi sisteminin kurulması da bu dönemde şirketlerin öncelikle ele alması gereken konularından birisi olmuştur. Bu çalışmaların tümü kredi riskinin yönetilmesine ilişkin çalışmalardan bazılarına işaret etmektedir. Kredi riski yönetimi, şirketlerin potansiyel müşterileri ile kredili çalışma kararının verilmesi öncesinde yapılması gereken risk belirleme, analiz ve risk değerlendirme faaliyetlerini içeren, riskin önlenmesi, azaltılması, taşınması veya transfer edilmesine yönelik stratejilerin risk değerleme sonuçlarıyla beraber ele alındığı bir süreç yönetimine işaret etmektedir. Risk değerlendirme, riskin belirlemesine yönelik çalışmaları ve şirketin borç ödeme kapasitesinin tespitine yönelik analiz faaliyetlerini içerir. Şirket ile çalışma kararının verilmesinde ve ilişkinin sürdürülmesinde müşterini tanı ( know your customer - KYC) kriterlerine uygun bir incelemenin yapılması beklenir. Bu inceleme, risk belirleme faaliyetinin içerisinde yer alır. Değerlendirme sonuçları, risk yönetim stratejileriyle birlikte ele alınarak kredi tahsis kararı verilir. Kredi koşulları belirlenir.

Bu makalenin amacı, kredi riski yönetiminin, birbirini takip eden ve aynı zamanda birbirleriyle ilişkili adımları ile bir süreç yönetimi olarak ele alınması gerektiğini göstermektir. Makalenin girişten sonraki ilk bölümünde kredi riskinin tanımı yapılarak, kredi riskine sebep olan iç ve dış faktörlere değinilmiştir. Makalenin ikinci bölümünde, kredi riski yönetiminin önemine dikkat çekilerek şirketlerde organizasyonel açıdan nasıl yönetilmesi gerektiğine değinilmiştir. Kredi politikalarının belirlenmesinde risk değerleme faaliyetinin öneminden bahsedilmektedir. Makalenin üçüncü bölümünde, kredi riski yönetimi genel risk yönetim sürecinin adımlarına uygun olacak şekilde ele alınmış ve çeşitli kredi yönetim fonksiyonları bu sürecin adımlarına ilişkin olarak tanımlanmıştır.

\section{2. ŞiRKETLERDE KREDi RISKININ OLUŞMASI}

\subsection{Kredi Riskinin Tanımı}

Kredi riski muhatabın ödeme zorluğu içerisinde bulunması, ödeme konusunda gönüllü olmaması veya zamanında ödemesini yapmaması durumunda kreditör kuruluşun zarar etme olasılığını ifade eder. Ödeme yükümlülüğü içerisinde bulunan tarafa borçlu (debtor) veya yükümlü (obligor), alacaklı tarafa da alacaklı (creditor) denir. Bankacılıkta verilen kredilerin kredi borçlusu ( borrower) tarafından kredi vadesinde bankaya geri ödenmemesi sonucu bankanın(lender) maruz kaldığı finansal zarar da kredi riski olarak tanımlanır. Kredi riski başka durumlarda da ortaya çıkmaktadır. Parasını bankadan çekmek konusunda sıkıntıya düşen mudi sahiplerine bankanın bu yükümlülüğünü yerine getirememesi riski, sigortalıların prim borçlarını sigorta şirketlerine zamanında ödememeleri sonucu sigorta şirketinin katlanacağı finansal zarar, tahvil yatırımcılarının anapara ve faiz alacaklarını tahsil edememeleri durumunda karşılaşabileceği zarar, türev piyasalarında çeşitli işlemlerde örneğin swap, forward ve benzeri işlemlerde taraflardan birinin işlem gereği yükümlülüğünü yerine getirmemesi sonucu diğer tarafın katlanacağı zarar, finansal kiralama şirketlerinin kira bedellerini tahsil edememelerinin sonucu katlandıkları zararlar ve faktoring işlemlerinde faktoring borcunun tahsil edilememesi sonucu oluşan finansal zararlar da bu kuruluşlar için kredi riski oluşturmaktadır. (Bouteille \& Pushner, 2013)

Kredi riski aynı zamanda şirketlerin ticari faaliyetlerinin yürütülmesi sırasında karşılaştığı finansal risklerden biridir. Bu risk aynı zamanda ticari alacak riski (trade credit risk) veya ticari risk (commercial risk) olarak da adlandırılır. Tedarikçinin kredili mal ve hizmet satışında bulunduğu müşterisinin (alıcl, borçlu) ödeme vadesinde ödemesini yapmaması, temerrüde (default) düşmesi veya iflas etmesi ( insolvency) sonucunda tedarikçinin karşılaşacağı finansal zarar, şirketin karşılaştığı kredi riskini ifade eder. Temerrüd, alııının (müşteri) fatura vadesinde ödemesini yapmaması durumudur. Alıcı iflas edebilir veya iflasa 
benzer durumlar dolayısıyla ödemeler askıya alınır ve ödeme gerçekleşmez. Kredi riski, şirketin yapmış olduğu kredili satışlara (credit sales )bağlı olarak gerçekleşen bir risktir. Mal ve hizmet tedarikinde bulunan tedarikçilerin ilk tercihleri mal veya hizmet bedellerini peşin olarak tahsil etmektir. Kredili satışlar ise işletmenin yapmış olduğu peşin olmayan vadeli satışlarıdır. Şirket müşterisine ödemesini belirli bir süre sonra yapma imkanı verdiğinde muhasebe kayıtlarında bu şirket için bir ticari alacak kalemi oluştururken, borçlu için ise bir ticari borç kalemi oluşur. Tedarikçi vadeli satış yaparak alıcıya bir kredi imkanı (supplier credit, trade credit) sunar. Alıcı bankadan kredi kullanmak yerine, tedarikçinin sağladığı kredi imkanından yararlanmaktadır. Alıcı bu kredi imkânından yararlanarak, kendi müşterisine de vadeli satış yapma imkânı sağlamaktadır. Tedarikçinin kredili satış yapmasının bir başka nedeni tüketicinin satın alma iştahının artmasini sağlamaktır. Yüksek gelir sahibi olan grubun nüfusun küçük bir kısmını oluşturduğu, yüksek enflasyonun görüldüğü ve ekonominin politik sebeplerle sürekli olarak dalgalandığı ekonomilerde toplumun büyük bir kesimi satın alma planlarını ertelemek ve elinde nakit para bulundurmak eğilimindedir. Bu durumda büyüme durmakta veya negatif büyüme gözlenmektedir. Böyle ekonomilerde, sirketler kredi riskini iyi yönetebilmek icin kredi riski düşük, büyük ve güçlü alıcılarla çalışmayı isterler. Orta ölcekli ve küçük üreticiler, servis sağlayıcıları ise pazarın ortalama vadesi veya daha uzerinde bir vade sağlayarak rekabet avantajı yaratmaya çalışırlar. Tedarikçinin kredili satış yapmasının sebeplerine ilişkin birçok teori vardır. (Bkz. Tablo 1) iş̧lem maliyeti teorisine göre kredili ticarette borç alacak ilişkisi süreklilik arz eder. Bu nedenle, satıcı ile alıcı arasında bir borçlu cari hesap işletilerek borcun her bir işlemde ödenmesi yerine toplu olarak belirlenmiş bir dönemin sonunda ödenmesi işlem maliyetini azaltır. Tedarikçilerin finansal açıdan daha güçlü olması bankalardan kredi kullanma maliyeti konusunda bir avantaj elde etmesine sebep olmaktadır. Tedarikçiler bu avantajı vadeli satış yaparak alıcılarına kanalize etmektedirler. Fonların akışı büyük firmalardan finansal açıdan göreceli olarak daha zayıf firmalara aktarılmaktadır. Bir diğer sebep talep dalgalanmalarında vade değişikliğinin alıcı için efektif fiyat değişikliğine yol açmasıdır. Fiyat ayırımcılığı olarak bilinen bu teoriye göre tedarikçiler diğer kredi alternatiflerine ulaşmakta zorluk çeken riskli müşteri grubuna vadeye göre değişen fiyat uygulamak yoluyla fiyatta farklılık yaratmaktadırlar. Kredi değerliliği yüksek alıcılar bu fiyat farkını üstlenmek istemezler ve peşin ödeme yoluna giderler. Alııının mal bedelini peşin ödemek yerine mal tesliminden sonra ödemesi ürünün kalitesi hakkında bir kontrol imkânı sağlar. Alıcı kalite konusunda emin olduğunda düzenli sipariş verir. (Çetiner \& Eke, 2018)

Şirketler kredili satış yapmak durumunda kaldıklarında müşterilerinden genellikle çeşitli garanti ve teminatlar talep ederler. Bina ipoteği maddi teminata bir örnektir. Uluslararası ticarette ödeme şekillerinden biri olan geri dönülemez ve teyitli akreditifler veya banka avalli poliçelerin kullanıldığı kabul kredili ihracat, ihracatçııın bu garanti ihtiyacının banka aracılığıyla karşılanmasına yöneliktir. Diğer yandan uluslararası ticarette alııının tercihi herhangi bir akreditif ve benzeri bir banka garantisi sunmaksızın, açık hesap (open account) mal almak yönündedir. Akreditifin getirdiği maliyetler ve taraflara getirdiği yükümlülükler düşünüldüğünde bu alıcı açısından haklı bir sebep olarak görülebilir. Buna ilave olarak, akreditif açma alıcının bankasıyla kredili bir çalışma içine girmesi anlamına gelmektedir. Şirketler özellikle finansal kriz döneminden başlayarak dönemin getirdiği sıkıntılar dolayısıyla yeni kredi limiti almak konusunda zaman zaman sıkıntı yaşayabilmektedirler. Ödeme şekillerinden mal mukabili ihracat olarak bilinen açık hesap ihracatta, ihracatçı mal ve hizmet sevkiyatında bulunur ve faturasını düzenler. Alıcı malları gümrükten çektikten sonra, faturada belirlenmiş ödeme vadesinde ödeme yapar. Alıcının vadede ödeme yapmaması ihracatçının taşıdığı kredi riskine işaret eder. Bu riskin yönetilmesi konusunda banka dışı çözümler önemli rol oynamaktadır. Faktoring ve kredi sigortası (ticari alacak sigortası) açık hesap ihracatı güvence altına almak amacıyla kullanılan risk yönetim araçlarıdır. Gayrikabilirücu faktoringde alıcının vadede ödememe riski garanti altına alınır. Kredi sigortası ise, diğer tüm mal varlığı ve sorumluluk risklerine ilişkin sigortalarda olduğu gibi, şirketin bilançosunda varlıklar arasında yer alan ticari alacakların vadesinde ödenmemesi riskine karşı güvence altına alınmasında kullanılan bir risk yönetim aracıdır. (Çetiner \& Eke, 2020)

\subsection{Kredi Riskine Sebep Olan Faktörler}

Dış kaynaklı riskler (external risks) örneğin deprem, sel ve yanardağ patlaması gibi doğal afet riskleri veya salgın hastalık riskleri şirket faaliyetlerinin yürütülmesi sırasında ortaya çıkan ve şirketin faaliyetlerinin aksamasına yol açan risklerdir. Bu risklerin gerçekleşmesi durumunda, şirket tesisleri zarar görür, üretim ve satış faaliyetleri aksar, satış ve kar kayıpları yaşanır. Bazı dış kaynaklı riskler, örneğin makroekonomik riskler ise şirketi finansal açıdan zorlayan risklerdir. Şirket finansal pozisyonuna bağlı olarak bu risklerden etkilenir. Şirketin faaliyet gösterdiği sektörün yapısal özellikleri ve sektörel riskler de benzer şekilde şirketin faaliyetlerinin yönünü belirler. Bazı yasal değişiklikler sadece belirli sektörlere yöneliktir. Bu değişiklerin sektör üzerinde ve spesifik olarak da şirket üzerindeki olumlu ya da olumsuz yöndeki etkisinin incelenmesi gereklidir. Şirkete özgü riskler, şirket faaliyetlerinin yürütülmesi sırasında karşılaşılan şirketiçi uygulamaların yetersizliği veya inmal gibi sebeplerle ortaya çıkan fiziki ve finansal kayıplara yol açan risklerdir. Faaliyet riskleri olarak adlanıdırılan bu riskler, mal varlığı kayıplarına yol açan risklerdir. Bu risklerden bazıları, 3. şahıslara verilen zararlardan dolayı şirkete ekstra bir sorumluluk yükler. Şirket yönetimlerinin bu riskleri yönetmesi beklenir. Buna ilave olarak şirketin karşılaşabileceği finansal riskler de, şirketin yönetmesi gereken riskler arasındadır. Gerek finansal, gerekse finansal olmayan risklerin gerçekleşmesi durumunda şirket faaliyetleri olumsuz yönde etkilenir. Şirket borcunu ödeyemez duruma düşer. Bu nedenle, risk analizinde şirket faaliyetlerinin anlaşılması, iş modellerinin sorgulanması ve şirketin değişen koşullar altında faaliyetlerini kesintisiz sürdürebilmesi için uyguladığı risk 
yönetim faaliyetlerinin incelenmesi son derece önemlidir. Aşağıda bu riskler hakkında kısa bilgiler yer almaktadır: (Joseph, 2013)

\subsubsection{Dış Çevre Riskleri}

Dış çevre riskleri, işletmenin faaliyetlerinden bağımsız olarak ortaya çıkan ve şirketlerde fiziki ya da finansal kayıplara yol açan risklerdir. Şirketin faaliyet gösterdiği ülkedeki makroekonomik göstergelerdeki değişimler şirketin faaliyetlerini olumlu ya da olumsuz yönde etkileyebilir. Deprem, sel gibi doğal afet riskleri, kuş gribi ve COViD-19 pandemisi gibi salgın riskleri dış kaynaklı riskler arasında yer alır. Şirketin faaliyette bulunduğu ülkedeki yasal değişikler de dış çevre riskleri arasında sayılabilir. Yasal değişiklikler, şirketin faaliyette bulunduğu sektörü ve spesifik olarak şirketi olumlu ya da olumsuz yönde etkileyebilir. Sınırötesi ticarette karşılaşılan politik riskler de şirketin kendi kontrolü dışında gerçekleşen ve yönetilmesi gereken risklerdir.

Özellikle ihracata yönelik faaliyet gösteren şirketler, alıcının ödeme kabiliyetinden bağımsız olarak ortaya çıkan politik riskleri de yönetmek durumundadırlar. Bu riskler, ihracatçının mal ve hizmet bedelinin tahsilini geciktiren veya engelleyen risklerdir. Bu risklerin gerçekleşmesi durumunda, ticaretin kontrat şartlarına göre yürütülmesi zorlaşır. Mal ve hizmet ihracatı yapılan ülkedeki konvertibilite sorunları, mal bedelinin ülkeden bir başka ülkeye transferi konusunda ortaya çıkan engellemeler, ithalat ya da ihracat lisansının iptali, savaş ve moratoryum ilan edilmesi gibi olağanüstü durumlar karşılaşılması muhtemel politik riskler arasında sayılabilir. İhracat kredi sigortası poliçelerinde bu risklerin bazıları sigorta şirketinin risk kabulüne bağlı olarak teminat altına alınmaktadır. (Jus, 2013) Politik riskler aynı zamanda sınırötesi yatırımlarda müteahhitlerin veya proje üstlenicilerinin, sponsorlarının veya finansörlerin karşılaştığı risklerdir. Politik riskler savaş hali, iç savaş, ihtilal, ayaklanmalar gibi olaylar neticesinde ortaya çıkabileceği gibi, yatırım faaliyeti ile ilgili hukuki çerçevede meydana gelen beklenmeyen değişiklikler veya siyasi iktidar değişikleri neticesinde yeni kurulan hükümetlerin yatırım faaliyetinin dayandığı sözleşmeleri feshetmesi ya da yeni şartlar getirecek şekilde sözleşmeleri gözden geçirmesinden kaynaklanabilmektedir. Ayrıca, politik riskler ev sahibi devletin kar transferlerini zorlaştırması veya geçici olarak askıya almasına ek olarak doğrudan veya dolaylı kamulaştırma veya devletleştirme olarak addedilebilecek eylemler neticesinde de ortaya çıkabilmektedir. Bu riskler politik risk sigortaları ile teminat altına alınmaktadır. (Gordon, 2008)

\subsubsection{Sektöre Özgü Riskler}

Şirketin faaliyet gösterdiği sektör, firmanın iş yapma biçimini, finansman yapısını ve varlık kompozisyonunu belirler. Yüksek teknoloji ile üretim yapan sektörlerde genellikle sabit kıymetler yüksek tutarlıdır. Bu bakımdan bu sektörlerde faaliyet gösteren firmaların sabit kıymet yatırımları yüksek tutarlarda olacaktır. Kullanılan krediler, yapılan yatırımlara bağlı olarak genellikle uzun vadeli krediler şeklinde olacaktır. Sektörde bir mevsimsellik sözkonusu ise, firmanın satışları da mevsimseldir. Mevsimsellik satışların yıl içerisinde farklı dönemlerde artış veya azalış kaydetmesi ile sonuçlanır. Sektörün yapısal özellikleri örneğin sektörde rekabet durumunun olup olmadığı, sektörün maliyet yapısı, teknolojik bağımlıı̆ı̆ın olup olmadığı gibi faktörler şirketin faaliyetlerini olumlu ya da olumsuz yönde etkiler. Şirketin rekabet edebilmek için teknolojiye önem vermesi, yenilikçi olması beklenir. Şirketin bu amaca uygun olarak finansman kaynaklarına ulaşabilmesi önemli hale gelir. Şayet şirket bu yatırımları gerçekleştiremeze veya finansman temin edemezse diğer firmalarla rekabet edemez, pazar kaybeder. Satış ve kar kaybı ile karşılaşan şirket borcunu da zamanında ödemeyebilir. Sektörde genel olarak talebin ciddi bir şekilde daralması sektörün yaşam eğrisinde düşüş evresinde olduğunu gösterir. Bu aşamada genel olarak sektörde faaliyet gösteren şirketlerin satışlarında azalma gözlemlenir. Düşüş evresinde olan bir sektördeki şirkete verilen kredinin geri ödemesinde sıkıntılar oluşabilir. Sektör analizi sadece sektörel risklerin değil aynı zamanda sektöre özgü fırsatların da dikkate alınmasını gerektiren bir çalışmadır.

\subsection{3. Şirkete Özgü Riskler}

Faaliyet riskleri, bir kurumun temel iş ve faaliyetlerini yerine getirmesini engelleyebilecek, iş süreçlerini etkileyebilecek risklerdir. Faaliyet riskleri yetersiz ve hatalı uygulamalar sonucu ortaya çıkar. Yangın riski, hırsızlık riski, terör riski, nakliye riski, ürün riski ve üretim sürecine ilişkin diğer riskler, bilgi işlem riskleri ve insan kaynağına ilişkin riskler şirketin yönetmesi gereken faaliyet riskleri arasında yer alır. Bu risklerin gerçekleşmesi durumunda şirketin mal varlığı zarar görür. Şirket iş durmasına bağlı olarak, satış ve kar kaybı ile karşılaşır. Bu risklerin sürekli hale gelmesi durumunda veya şirkette telafi edilmesi mümkün olmayan bir hasara sebep olması durumunda şirket pazar kaybı, itibar kaybı sorunları ile karşılaşabilir, borçlarını ödeyemez duruma düşebilir ve hatta iflas söz konusu olabilir. (Hopkin, 2017) İş durmasına yol açan yangın, deprem ve benzeri mal varlığı riskleri sigortalanabilen riskler arasındadır. İş durmasına bağıı oluşan satış ve kar kaybı riski de sigortalanabilmektedir. (Allianz Global Corporate \& Specialty, 2020)

Finansal riskler, şirketin varlık ve borç yapısına bağı olarak ortaya çıkan ve finansal yönetim teknikleri kullanılarak yönetilen risklerdir. Finansal riskler, piyasa riskleri, kredi riski ve likidite riskini içerir. Piyasa riskleri, firmanın piyasa fiyatlarındaki dalgalanmalar neticesinde karşılaşabileceği riski ifade eder. Faiz oranlarındaki değişimler neticesinde faize bağı finansal varlıkların muhtemel kayıplarını ifade eden faiz oranı riski , döviz kurundaki değişimler neticesinde işletmelerin varlık, kaynak 
ve gelir giderlerini etkileyen döviz kuru riski, piyasa riskleri içerisinde yer alır. Şirketin sahip olduğu varlıkların istenildiğinde nakde kolaylıkla çevrilememesi veya değerinin altında çevrilmesi sonucu, şirketin borçlarını ödeyememesi ile sonuçlanan risk ise likidite riski olarak tanımlanır. Kredi riskinin artması, tahsili mümkün olmayan alacaklarda artışa sebep olur ve likidite riskine yol açar. Finansal risklerini yönetemeyen şirketler iflas riski yaşarlar . (Holliwell, 1998)

\section{3. ŞiRKETLERDE KREDi RISK YÖNETIMi}

\subsection{Amaç ve Bağlam}

Kredi riski yönetiminin temel amacı, müşteri portföyündeki borçluların geri ödeme kabiliyetlerinin tespit edilmesi ile şirkete değer yaratan müşteri portföyünün oluşturulması ve kredilendirme fonksiyonunun karlı bir şekilde sürdürülebilmesidir. Şirketin satış cirosu hedeflerini gerçekleştirebilmesi ve yeni müşteriler elde ederek büyüyebilmesi için şirketin karşılaşabileceği ticari alacak riskinin yönetilmesi son derece önemlidir. (Becue, 2013) Şirketin işletme sermayesi, likidite ve finansman yönetiminde ticari alacaklar önemli bir yere sahiptir. Şirketin bilançosunun çok önemli bir kısmı ticari alacaklardan oluşur. Ticari alacaklarını vadesinde tahsil edemeyen şirketin finansman ihtiyacı artar, şirket likidite sıkıntısı çeker. Borçlarını zamanında ödeyemez ve iflasa sürüklenir. Şirket sermayedarlari ve yatırımcılar şirkete yatırdıkları sermayeden bir getiri beklerler. Ticari alacakların tahsilat kabiliyetinin azalması yani temerrüt riskinin artması şirket ortaklarının alacaklara bağladıkları sermayeden bekledikleri karlılığın düşmesine sebep olur. Şirketin kredi riskini doğru yönetmesi temerrüt riskinin azaltılmasına yöneliktir. (Berk, 2000) Şirketin risk alma iştahına bağlı olarak, şirket risk kabul seviyesinin üstünde kalan müşteriler ile daha yüksek bir karlıık oranı ile çalışmayı hedefleyebilir. Bununla birlikte, riskin gerçekleşme olasııı̆ının yüksek olması, tahsili mümkün olmayan alacak düzeyinde artışa sebep olabilir. Tahsilat masrafları artar. Alacaklara bağlanan sermayenin fırsat maliyeti yükselir. (Kontus, 2013)

Şirketlerde kredi riski yönetimi , finans bölümleri altinda yapılandırılan kredi kontrol bölümleri tarafından yürütülür. Bu bölüm bazı sirketlerde CFO'ya direk bağlı bir bölüm olarak konumlanır. Bayi ağının cok geniş olduğu veya uluslararası ticaretin yoğun oldugu firmalarda bu fonksiyon bir kredi komitesi tarafından yönetilir. Bu komiteye kredi müdürü, $\mathrm{CFO}$, genel müdür ve satış direktörleri katılır .Kurumsal sirketlerde belirli yetkilendirme seviyeleri bulunur ve bu seviyelere göre Genel müdür-CEO , CFO ve kredi kontrol müdürünün yetki seviyeleri belirlenir. Bu komite kredi politikasını belirler ve gerekirse degisiklikleri onaylar. Kredi politikası belirli dönemlerde kredi komitesi tarafından gözden geçirilir. Kredi politikasında, yeni ve mevcut musteriler icin, kredilendirmenin hangi standartlara göre yapılacağını belirleyen yönlendirmeler, kredi analiz ve onay sürecini düzenleyen kurallar, kredi karar mekanizmalarının nasıl işlemesi gerektiğini gösteren ve kredi onayı konusunda kimlerin hangi yetki ve sorumluluklara sahip olduğunu gösteren kurallar ve tahsilat politikasına ilişkin kararlar yer alır . (Lam, 2003) Tahsilat politikası tahsilatın şirket içi veya şirket dışı hangi yöntemlerle yapılacağını, idari ve yasal takibe ilişkin yöntemleri ifade eder. (Bottoni, 2001)

Kredilendirme kararı risk değerleme faaliyetinin sonucuna göre belirlenir. Bu kararın verilmesi sırasında riskin önlenmesi, azaltılması veya transfer edilmesine ilişkin risk yönetim stratejileri gözönünde bulundurulur. Kredi tahsis kararı ile birlikte kredi koşulları belirlenir. Kredi koşullarından biri olan kredi vadesi, ödemesini belirli bir vade sonunda yapması için alıcıya verilen süreyi gösterir. Kredi limiti, herhangi bir zamanda ödemenin gerçekleşmemesi durumunda tedarikçinin katlanacağı maksimum zarar tutarını belirler. Şirketler çalışma kararı aldıkları müşterileri için bir kredi limiti belirlerler. Örneğin, alıcıya 100.000 USD'ık tek bir yükleme yapılmışsa ve alıcının kredi limiti 100.000 USD ise, tedarikçinin ödemenin gerçekleşmemesi durumunda katlanacağı zarar 100.000 USD’ı geçemez. Tedarikçi, kredi limiti dâhilinde yükleme yapabilir ve bu tutarın üstünde riske girmez. Kredi limitlerinin belirlenmesinde alıcıya yapılan yıllık tahmini satışlar ve ortalama ödeme vadesi dikkate alınır. Kredi limitleri, risk değerlendirme sonuçlarına göre belirli aralıklar gözden geçirilir. (Edwards, 2010) Teknik veya farklı sebeplerle ödeme vadesi kredi vadesine esit olmayabilir. Örneğin, ihracatta bankalararasi para transferinde aracı bankaların sürece dahil olmasi veya bankalarin kendi iç prosedürleri sebebiyle 1 hafta 10 güne kadar gecikme olabilmektedir. Bunun yanı sıra, müşteriler de kendi nakit akışlarına göre planlama yapıp süreci uzatabilmektedirler. Bu nedenle kredi limitinin hesaplaması yapııırken ödeme vadesini dikkate almak tedarikçilerin ilave bir riskle karşılaşmasını önleyecektir.

Kredi standartları, hangi tip şirketlere hangi kredi koşulları ile kredi verilebileceğine ilişkin kurallardan oluşur. Burada amaç, kredi koşularının taşınan riskle uyumlu hale getirilmesidir. Risk değerleme sonucuna göre şirketler kredi riskinin derecesine göre gruplandırılır. Kredi koşulları (limit, vade, teminat) bu gruplandırmalara uygun olarak belirlenir. Şirketler bu amaçla, müşteri portföyünü oluşturan şirketler arasında belirli kriterlere göre kıyaslama yapılabilmesini sağlayan bir iç derecelendirme sistemi kurabilirler. Şirketlerde kredi derecelendirme sisteminin kurulması ile ilgili standart bir yöntem sözkonusu olmamakla birlikte şirketler riskin değerlendirilmesine yönelik elde ettikleri bilgi ve belgeleri dikkate alarak bir derecelendirme sistemi kurabilirler. Bu değerlendirmede ilk sene daha konservatif bir yaklaşım sergilenirken, müşterinin ödeme geçmişine göre yıllar icerisinde daha fazla esneklik sağlanabilmektedir. Özellikle uzun yıllardır ticari ilişkinin devam ettiği, ödemelerinde sorun yaşanmayan, organizasyonlari stabil ve tedarikçiye bağlıı̆̆ı yüksek şirketler icin tedarikçi firmalar yeni müşterilere göre daha esnek bir yaklaşım sergilemektedirler. Daha uzun vadede satış yapılmasına veya belirli bir oranda açık hesap satış yapılmasına 
karar verilebilir. Kredi politikasında esnekliğe gidilmesinde, kredi kontrol bölümünün süreci iyi yönetmesi beklenir. Kredi politikasında esnekliğin sağlanabilmesi için belirli sınırlamaların önceden belirlenmesi ve karar altına alınması gereklidir. Şirkete bağı, uzun süredir çalışan müşterilerin ayrıcalıklı değerlendirilmesi, aradaki bağı kuvvetlendireceği gibi sadece bu sebeple fazla esneklik sağlamak bu müşterinin ileriki zamanlarda kontrol dışına çıkmasina sebebiyet verebilir ve bu da şirket açısından riskli bir durum oluşturur. Derecelendirmedeki en basit yöntem, değerlendirme sonucuna göre kredi riskinin nispeten daha düşük olduğu kabul edilen şirketleri örneğin özvarlığı yüksek, satışlarında veya karlılığında artışlar gözüken şirketleri en iyi derece ile örneğin A derecesi ile sınıflamak, borçluluğu yüksek, sermayesi düşük, gecikmeli ödeyen şirketleri ise örneğin $C$ kategorisinde değerlendirmektir. Kredilendirme sonrası izleme faaliyetinde $A$ kategorisinde yer alması gereken bir şirket, ödemelerini zamanında yapmadığı için ara sınıf olan B veya yüksek risk sınıfı olan C kategorisine kaydırılabilir. Ancak, yüksek riskli ya da az riskli tanımı çok subjektif olabileceğinden, belli finansal rasyoların da (karılık, borçluluk gibi) müşteri portföyü üzerinde uygulanmasıyla risk kategorilerini belirlemek mümkündür. Bu kategorilerin oluşturulması aşamasında, sadece rasyo analiziyle yetinilmeyip, örneğin müşterinin eski ya da yeni müşteri olup olmadığı, daha evvel ödemelerinde bir gecikme sorunu yaşanıp yaşanmadığı veya müşteriden teminat alınıp alınmadığı gibi kriterler belirlenerek bu kriterlere ağırlık puanları verilebilir. Veri olarak yüklenen bu bilgilerin ağırlık puanlarına göre riskin ağırlıklı ortalaması her müşteri ya da müşteri grubu için hesaplanır. Çıkan neticelere göre belli skalalar oluşturularak derecelendirme notları bu skalalara uygun olarak verilir. Bu derecelendirme notlarına bağlı olarak bir takım performans göstergeleri ilave edilebilir. Şöyle ki, en az riskli gruba verilen A derecesi alan şirketlere tanınacak kredi limiti, özvarlığın veya şirket işletme sermayesinin yine belli bir yüzdesi olarak tanımlanır. Bu şirketlere tanınan kredi limiti diğerlerinden yüksek olarak belirlenebilir. A derecesi alan şirketlerin teslimat önceliği olabilir. Bu şirketler hatırlı müşteriler grubunda yer aldığından müşteri ziyaret planları buna göre oluşturulabilir. Bu şirketlerin gerekirse nakit iskontosu gibi satış teknikleri kullanılarak peşin satış için teşvik edilmesi planlanır. Fiyat politikaları buna göre belirlendiği gibi herhangi bir uyuşmazlıkta veya olası tahsilat probleminde problemin çözülmesine dönük önceliklerin bu müşteri grubuna gecikmeksizin verilmesi gerekmektedir. Benzer şekilde, diğer derecelendirme notlarına göre de teslimat öncesi ve teslimat sonrası hizmet standartlarının belirlenmesi mümkündür. Bu standartların bilgi işlem sistemi üzerinde kaydedilmesi, standartlara uygunluk veya standartlardaki değişikliklerin yapılmasına yönelik olarak karar alma süreçlerine yardımcı olması açısından önemlidir. (Bullivant, 2010)

\subsection{Literatür Taraması}

Yazın taramasında, bankacılıkta kredi riski yönetim sürecine ilişkin çok sayıda makaleye rastlanmıştır. Şirketlerde kredi riskinin yönetilmesine ilişkin süreci bütünüyle ele alan bir makaleye yazın taramasında rastlanmamıştır. Bu konuda kaynaklar genellikle bu makalenin referanslar listesinde yer alan kitaplar, çeşitli uluslararası kuruluşların yayınladığı pdf ve benzeri rapor ve yayınlardır. Bunun sebebi, risk yönetiminin uygulamaya yönelik bir konu olması ve çeşitli uluslararası kuruluş ve organizasyonların yön gösterici düzenlemelerine uygun bir şekilde şirketlerde yürütülmesidir. Şirketlerde finans yöneticileri genellikle kredili satışlara bağlı olarak ortaya çıkabilecek temerrüt riskinin şirket kar ve zararı üzerindeki etkisinin hesaplanması, kredi koşullarının belirlenmesinde temerrüt riski etkisinin dikkate alınması, riskin oluşması ihtimalinin hesaplanarak karşılık ayrılması, alacağın geç tahsilinin veya tahsil edilememesinin şirketin işletme sermayesi yönetimi üzerindeki etkisinin hesaplanması ve likidite ihtiyacının belirlenmesi gibi finansal konularla ilgili çalışmalar yapmaktadırlar. Risk yönetimi ise kredi riskinin oluşmasına sebep olan faktörlerin tespiti ile başlayan, riskin erken teşhisine yönelik risk değerlendirme yöntemlerinin kullanıldığı, riskin kontrolü ve transferi için proaktif çözümleri içeren bir süreç yönetimine işaret etmektedir. Yazın taraması yapıldığında yazılan makalelerin ağılıklı olarak üç başlıkta toplandığı görülmektedir. Kredili ticaretin sürdürülmesinde teoriler (theory of trade credit ) başlığı altında yer alan makaleler, şirketlerin kredili ticarete devam etmelerinin sebeplerini teorik düzeyde ele alan çalışmalardır. Bu bölümde yer alan makalelerin bazılarında tedarikçi kredisinin ticaretin sürdürülebilirliğine olan katkısı analiz edilmektedir. Tedarik zincirinde ticari akışların sürdürülmesinde tedarikçinin karşılaştığı kredi riskinin teminat altına alınması son derece önemlidir. İkinci başlık altında yer alan makalelerde, riskin değerlendirilmesine yönelik çalışmalar yer almaktadır. Finansal ve finansal olmayan veriler istatistiki yöntemlerle analiz edilmektedir. Geleneksel analiz yöntemlerinin yanısıra, yapay zeka uygulamalarının da risk değerlendirme çalışmalarında kullanıldığı gözlemlenmektedir. Kredi riskinin transferinde kullanılan risk transfer araçlarının mikro ve makro açıdan önemini inceleyen makaleler üçüncü başlık altında yer almaktadır. Bu makalelerde, ampirik veriler kullanılarak ihracat kredi sigortasının ihracatta artış etkisi analiz edilmiştir. Faktoring konusu ile ilgili yazılan akademik makaleler sınırlı sayıda olmakla birlikte, tedarikçi kredisinin garanti altına alınmasında faktoringin rol ve önemini anlatan ve ticaretin gelişimine sağladığı katkıyı değerlendiren makaleler mevcuttur. Gerek ihracat kredi sigortası gerekse faktoring uluslararası ticaret finansmanında kullanılan finansal araçlardır. Bu nedenle, akademik literatürün yanısıra konuyla ilgili çok sayıda uluslararası dernek ve kuruluş bu araçların kullanımına ilişkin şirketlere yön gösteren raporlar yayınlamaktadır. Aşağıda Tablo 1'de bu makalelerin bazılarına yer verilmiştir. 
Tablo 1: Literatür Taraması

\begin{tabular}{|c|c|c|c|c|}
\hline Yazar & Makalenin Adı & $\begin{array}{l}\text { Yayınlandığı } \\
\text { Yıl }\end{array}$ & Makale konusu & $\begin{array}{l}\text { Yayınlandığı } \\
\text { Akademik } \\
\text { Dergi }\end{array}$ \\
\hline \multicolumn{5}{|c|}{ Kredili Ticaretin Sürdürülmesiyle İlgili Çalışmalar } \\
\hline Li, Zhen \&Cai & $\begin{array}{l}\text { Trade Credit } \\
\text { Insurance, Capital } \\
\text { Constraint and the } \\
\text { Behaviour of } \\
\text { Manufacturers and } \\
\text { Banks }\end{array}$ & 2014 & $\begin{array}{l}\text { Tedarikçi kredisi tedarikçiye satışlarını arttırma } \\
\text { konusunda bir rekabet avantajı sağlamaktadır. }\end{array}$ & $\begin{array}{l}\text { Springer } \\
\text { Science and } \\
\text { Business } \\
\text { Media }\end{array}$ \\
\hline $\begin{array}{l}\text { Long,Malitz \& } \\
\text { Ravid }\end{array}$ & $\begin{array}{l}\text { Trade Credit Quality } \\
\text { Guarantees and } \\
\text { Product Marketability }\end{array}$ & 1993 & $\begin{array}{l}\text { Tedarikçi alacaklara yatırım yapmış olur ve getiri elde } \\
\text { etmek ister. Alıcı ise bir finansman imkanı elde } \\
\text { etmektedir. Talep dalgalanmalarında tedarikçi vade } \\
\text { farklıı̆̆ı yaratarak, fiyat farklıığı sağlanmış olur. (Faaliyet } \\
\text { esnekliği teorisi). Talep düştüğünde kredi vadesi } \\
\text { esnetilerek alıcının efektif fiyatının düşürülmesi yoluyla } \\
\text { nominal yatırım düzeyinin korunacağı ve talep artışında } \\
\text { ise kredi vadesinin kısaltılabileceği önerilmektedir. }\end{array}$ & $\begin{array}{l}\text { Fianncial } \\
\text { Management }\end{array}$ \\
\hline $\begin{array}{l}\text { Petersen \& } \\
\text { Raghuran }\end{array}$ & $\begin{array}{l}\text { Trade Credit Theories } \\
\text { and Evidence }\end{array}$ & 1997 & $\begin{array}{l}\text { Kredili ticaret işlem maliyetini azaltır. (İşlem maliyeti } \\
\text { teorisi). Alıcı finansman imkanı elde eder. Büyük ölçekli } \\
\text { şirketler elde ettikleri düşük maliyetli finansman } \\
\text { imkanlarını kredili satış yapmak yoluyla alıcılara aktarmış } \\
\text { olurlar. (Finansal aracılık teorisi). Tedarikçiler firma } \\
\text { bilgisine daha kolay ulaşırlar. Ticarette devamlılık söz } \\
\text { konusudur. Tedarikçiler firma bilgisine daha kolay } \\
\text { ulaşırlar. Riskin izlenmesi ve riskin tahsili konusunda } \\
\text { erken hareket etme kabiliyeti yüksektir. Şirketin ürün } \\
\text { fiyatı alıcılarınn kredi değerliliği arasındaki farkı dikkate } \\
\text { almaz ve aynı fiyat uygulanır. Kredi değerliliği düşük } \\
\text { firma aynı fiyatı vadeli alımda üstlenir ve efektif fiyat } \\
\text { düşer. Kredi değerliliği yüksek firma ise finansman } \\
\text { maliyetini yüksek bulur ve erken ödeme yapmak ister. } \\
\text { (Fiyat ayırımcılığı teorisi). Alıılar hakkında bilgi edinme } \\
\text { kolaylığı, alacaklarını tahsil etmekte çabuk hareket } \\
\text { edebilme becerisi bankalara kıyasla şirketlerin daha fazla } \\
\text { risk almasına olanak sağlar. Banka kredilerine ulaşım } \\
\text { imkanının zorlaştığı dönemlerde alıcılar, tedarikçi } \\
\text { kredisinden daha fazla yararlanabilmektedirler. }\end{array}$ & $\begin{array}{l}\text { The Review of } \\
\text { Financial } \\
\text { Studies }\end{array}$ \\
\hline Smith & $\begin{array}{l}\text { Trade Credit And } \\
\text { Informational } \\
\text { Asymmetry }\end{array}$ & 1987 & $\begin{array}{l}\text { Kredili mal satışı ürünün kalitesinin test edilmesi } \\
\text { konusunda alıcıya bir imkan sağlar. Asimetrik bilgiyi } \\
\text { azaltır. (Kalite göstergesi teorisi). Alıcı bu nedenle vadeli } \\
\text { alım yapmak ister. }\end{array}$ & $\begin{array}{l}\text { The Journal of } \\
\text { Finance }\end{array}$ \\
\hline Mian \& Smith & $\begin{array}{l}\text { Accounts Receivable } \\
\text { Management Policy: } \\
\text { Theory and Evidence }\end{array}$ & 1992 & $\begin{array}{l}\text { Tedarikçi satış süresi boyunca alıcı ziyaret eder ve bilgi } \\
\text { edinir. Bu nedenle, bilgi edinme maliyeti bankalara göre } \\
\text { daha düşüktür. }\end{array}$ & $\begin{array}{l}\text { The Journal of } \\
\text { Finance }\end{array}$ \\
\hline $\begin{array}{l}\text { Fernando \& } \\
\text { Muller }\end{array}$ & $\begin{array}{l}\text { Do Firms Use the } \\
\text { Trade Credit Channel } \\
\text { to Manage Growth? }\end{array}$ & 2013 & $\begin{array}{l}\text { Şirketler üretimlerini arttırmak için bir finansman } \\
\text { kaynağı olarak tedarikçi kredisinden yararlanırlar. } \\
\text { Finansal sıkışıklık dönemlerinde tedarikçi kredisi önemli } \\
\text { bir finansman kaynağı haline gelir. }\end{array}$ & $\begin{array}{l}\text { Journal of } \\
\text { Banking } \\
\text { \&Finance }\end{array}$ \\
\hline Nilsen J. & $\begin{array}{l}\text { Trade Credit and Bank } \\
\text { Lending Channel }\end{array}$ & 2002 & $\begin{array}{l}\text { Tedarikçi teslim edilmiş mallarla ilgili alıcıya geç ödeme } \\
\text { yapmak konusunda bir imtiyaz sağlar. Alıcı banka } \\
\text { kredisine alternatif bir finansman kaynağına ulaşır. Küçük } \\
\text { ölçekli şirketler tedarikçi kredisinden daha fazla } \\
\text { yararlanırlar. }\end{array}$ & $\begin{array}{l}\text { Journal of } \\
\text { Money, } \\
\text { Credit and } \\
\text { Banking }\end{array}$ \\
\hline Fisman \&Love & $\begin{array}{l}\text { Trade Credit, } \\
\text { Financial } \\
\text { Intermediary } \\
\text { Development and } \\
\text { Industry Growth }\end{array}$ & 2003 & $\begin{array}{l}\text { Finansal piyasaların daha az gelişmiş olduğu ülkelerde } \\
\text { tedarikçi kredisi kullanan sektörlerdebüyüme daha hızlı } \\
\text { olmaktadır. }\end{array}$ & $\begin{array}{l}\text { The Journal of } \\
\text { Finance }\end{array}$ \\
\hline
\end{tabular}




\begin{tabular}{|c|c|c|c|c|}
\hline Yazar & Makalenin Adı & $\begin{array}{l}\text { Yayınlandığı } \\
\text { Yıl }\end{array}$ & Makale konusu & $\begin{array}{l}\text { Yayınlandığı } \\
\text { Akademik Dergi }\end{array}$ \\
\hline \multicolumn{5}{|c|}{ Şirketlerde Kredi Riskinin Değerlendirilmesiyle İlgili Çalışmalar } \\
\hline $\begin{array}{l}\text { Kallberg } \\
\text { J.,Udell G. }\end{array}$ & $\begin{array}{l}\text { The Value of Private } \\
\text { Sector Business Credit } \\
\text { Information Sharing: The } \\
\text { US Case }\end{array}$ & 2003 & $\begin{array}{l}\text { Riskin teşhisinde ve önlenmesinde kredi } \\
\text { istihbarat kuruluşlarının rolü incelenmiştir. D\&B } \\
\text { kredi istihbarat şirketinin sunduğu hizmetler } \\
\text { değerlendirilmiştir. }\end{array}$ & $\begin{array}{l}\text { Journal of Banking } \\
\text { \&Finance }\end{array}$ \\
\hline $\begin{array}{l}\text { Wang, Zhao \& } \\
\text { Peng }\end{array}$ & $\begin{array}{l}\text { Trade Credit Contracting } \\
\text { Under Asymmetric Credit } \\
\text { Default Risk }\end{array}$ & 2017 & $\begin{array}{l}\text { Tedarikçinin karşılaştığı kredi riskinin } \\
\text { önlenmesinde bilgi almanın önemine } \\
\text { değinilmiştir. }\end{array}$ & $\begin{array}{l}\text { Elsevier Journal of } \\
\text { Operational } \\
\text { Research }\end{array}$ \\
\hline Pike \& Cheng & $\begin{array}{l}\text { Credit Management: An } \\
\text { Examination ofPolicy } \\
\text { Choices, Practices and } \\
\text { Late paymentin UK } \\
\text { Companies }\end{array}$ & 2001 & $\begin{array}{l}\text { Merkezi olmayan kredi operasyonlarında riske } \\
\text { göre kredi vadesinin belirlenmesinin riskin } \\
\text { riskin kontrol edilmesindeki rolü } \\
\text { sorgulanmıştır. }\end{array}$ & $\begin{array}{l}\text { Journal of Business } \\
\text { Finance \& } \\
\text { Accounting }\end{array}$ \\
\hline $\begin{array}{l}\text { Cancer \& Knez- } \\
\text { Riedl }\end{array}$ & $\begin{array}{l}\text { Why and How to } \\
\text { Evaluate the Credit } \\
\text { Worthinessof SMEs } \\
\text { Business Partners }\end{array}$ & 2005 & $\begin{array}{l}\text { Şirket içi bir risk değerlendirme sistemi } \\
\text { kurulmasının önemine değinilmiştir. }\end{array}$ & $\begin{array}{l}\text { International Small } \\
\text { Business Journal }\end{array}$ \\
\hline $\begin{array}{l}\text { Yoshino \& } \\
\text { Taghizadeh- } \\
\text { Hesary }\end{array}$ & $\begin{array}{l}\text { Analytical Framework on } \\
\text { Credit Risks for Financing } \\
\text { Small and Medium Sized } \\
\text { Enterprises in Asia. }\end{array}$ & 2014 & $\begin{array}{l}\text { Kredi riskinin analizine yönelik bir finansal ve } \\
\text { finansla olmayan verilerin yer aldığı bir veri } \\
\text { tabanının oluşturulmasının önemine } \\
\text { değinilmiştir. }\end{array}$ & $\begin{array}{l}\text { Asia Pacific } \\
\text { Development } \\
\text { Journal }\end{array}$ \\
\hline Shi \& Zung & $\begin{array}{l}\text { An Incentive Compatible } \\
\text { Solution for Trade Credit } \\
\text { Termin Corporating } \\
\text { Default Risk }\end{array}$ & 2010 & $\begin{array}{l}\text { Tedarikçinin kredili satışlarının planlanmasında } \\
\text { temerrüt etkisinin dikkate alınması gerektiğini } \\
\text { gösteren bir çalışmadır. }\end{array}$ & $\begin{array}{l}\text { European Journal of } \\
\text { Operations Research }\end{array}$ \\
\hline Kouvelis \&Zhao & $\begin{array}{l}\text { Financing the } \\
\text { newsventor: Supplier vs } \\
\text { Bank and the Structureof } \\
\text { Pptimal trade credit } \\
\text { contracts }\end{array}$ & 2012 & $\begin{array}{l}\text { Tedarikçinin kredili satışlarının planlanmasında } \\
\text { temerrüt etkisinin dikkate alınması gerektiğini } \\
\text { gösteren bir çalışmadır. }\end{array}$ & Operations Research \\
\hline $\begin{array}{l}\text { Zang, Luo, } \\
\text { Dong } \\
\text { \&Segerstedt }\end{array}$ & $\begin{array}{l}\text { Supply Chain } \\
\text { Coordination with Trade } \\
\text { Credit and Quantity } \\
\text { Discount Incorporating } \\
\text { Default Risk }\end{array}$ & 2014 & $\begin{array}{l}\text { Tedarikçi kredisine bağlı ortaya çıkan temerrüt } \\
\text { durumunun tedarik zincirine etkisini ele alan } \\
\text { bir çalışmadır. }\end{array}$ & $\begin{array}{l}\text { Intenational journal } \\
\text { of Production }\end{array}$ \\
\hline $\begin{array}{l}\text { Klapper \& } \\
\text { Laeven \& Rajan }\end{array}$ & Trade Credit Contracts & 2012 & $\begin{array}{l}\text { Asimetrik bilginin olduğu durumlarda } \\
\text { tedarikçinin müşteri seçiminde kredi vadelerini } \\
\text { kullarak riskikontrol edebileceği söylenmiştir. }\end{array}$ & $\begin{array}{l}\text { Review of Financial } \\
\text { Studies }\end{array}$ \\
\hline Behr \& Gitler & $\begin{array}{l}\text { Credit Risk Assessment } \\
\text { and Relationship } \\
\text { Lending: An } \\
\text { Empiricalanalysis of } \\
\text { German Small and } \\
\text { Medium Sized } \\
\text { Enterprises }\end{array}$ & 2007 & $\begin{array}{l}\text { Almanya'da KOBi'lere verilen kredilerde } \\
\text { temerrüt riskinin skorlama çalışmaları ile analiz } \\
\text { edilebileceğiampirik verilerle test edilmiştir. }\end{array}$ & $\begin{array}{l}\text { journal of Small } \\
\text { Business } \\
\text { Management }\end{array}$ \\
\hline Li, Zhen \& Cai & $\begin{array}{l}\text { Trade Credit Insurance, } \\
\text { Capital Constraint \& the } \\
\text { Behaviour of } \\
\text { Manufacturers and } \\
\text { Banks }\end{array}$ & 2014 & $\begin{array}{l}\text { Kredi sigortasının önemi değinilerek, banka } \\
\text { finansmanındaki rolü değerlendirilmiştir. }\end{array}$ & $\begin{array}{l}\text { Annals of } \\
\text { Operations Research }\end{array}$ \\
\hline Wang \& Lou & $\begin{array}{l}\text { Seller's Optimal Credit } \\
\text { Period and Cycle Time in } \\
\text { a Supply Chain } \\
\text { Deteriorating Items with } \\
\text { Maximum Lifetime }\end{array}$ & 2015 & $\begin{array}{l}\text { Sermaye sıkışıklığı olan şirketlere verilen } \\
\text { kredilerde şirketin kullandığı kredi sigortasının } \\
\text { riski iyileştirenbir araç olarak kullanılması } \\
\text { gerektiğine dikkat çekilmiştir. }\end{array}$ & $\begin{array}{l}\text { European Journal of } \\
\text { Operations Research }\end{array}$ \\
\hline Erdoğan O. & $\begin{array}{l}\text { Corporate Credit risk } \\
\text { assessment of BIST } \\
\text { companes }\end{array}$ & 2018 & $\begin{array}{l}\text { Kredi riskinin değerlendirilmesi ve } \\
\text { derecelendirilmesine ilişkin modellerin ele } \\
\text { alındığı bir çalışmadır. }\end{array}$ & $\begin{array}{l}\text { European Scientfic } \\
\text { Journal }\end{array}$ \\
\hline
\end{tabular}




\begin{tabular}{|c|c|c|c|c|}
\hline Tahırlı A. & $\begin{array}{l}\text { Account receivable } \\
\text { Management, } \\
\text { description and } \\
\text { samplingtechniques }\end{array}$ & 2017 & $\begin{array}{l}\text { Şirketlerde ticari alacak yönetimine değinilerek } \\
\text { alacağın tahsili konusunda kontrol noktalarının } \\
\text { nelerolabileceği konusunda örneklere yer } \\
\text { verilmiştir. }\end{array}$ & $\begin{array}{l}\text { İstanbul Aydın } \\
\text { Üniversitesi Dergisi }\end{array}$ \\
\hline $\begin{array}{l}\text { Kanapickiene R, } \\
\text { Spicas R. }\end{array}$ & $\begin{array}{l}\text { Credit Risk Assessment } \\
\text { Model for Small and } \\
\text { Micro-EnterprisesThe } \\
\text { Case of Litvania }\end{array}$ & 2019 & $\begin{array}{l}\text { Finansal ve finansal olmayan veriler kullanılarak } \\
\text { istatiski yöntemlerle KOBİ statüsündeki } \\
\text { şirketlerin kredi riski analiz edilmiştir. Analizde } \\
\text { karlılık, likidite, borçlanma ve faaliyet oranları } \\
\text { dikkate alınmıştır. }\end{array}$ & Risks \\
\hline $\begin{array}{l}\text { Ning C., } \\
\text { Bernardete R, } \\
\text { Chen A. }\end{array}$ & $\begin{array}{l}\text { Financial Credit Risk } \\
\text { Assessment: A Recent } \\
\text { Review }\end{array}$ & & $\begin{array}{l}\text { Geleneksel istatistiki risk değerlendirme } \\
\text { metodları ve yapay zeka tabanlı kredi riski } \\
\text { değerlendirme yöntemlerikarşılaştırmalı olarak } \\
\text { incelenmiştir. }\end{array}$ & $\begin{array}{l}\text { Artificial Intellegince } \\
\text { Review }\end{array}$ \\
\hline $\begin{array}{l}\text { Delen D,Kuzey } \\
\text { C,UyarA }\end{array}$ & $\begin{array}{l}\text { Measuring firm } \\
\text { performance using } \\
\text { financial ratios: a } \\
\text { decision tree approach. }\end{array}$ & 2013 & $\begin{array}{l}\text { Seçilmiş finansal rasyolar üzerinden algoritmik } \\
\text { model ile firma riski analiz edilmiştir. }\end{array}$ & $\begin{array}{l}\text { Journal of Business } \\
\text { Finance \& } \\
\text { Accounting }\end{array}$ \\
\hline Chen \&Sheng & $\begin{array}{l}\text { A study of building risk } \\
\text { evaluation system for } \\
\text { supply chain financial } \\
\text { credit. }\end{array}$ & 2014 & $\begin{array}{l}\text { Finansal ve finansal olmayan verilerden } \\
\text { yararlanılarak bir risk değerleme modeli } \\
\text { üzerinde çalışılmıştır. }\end{array}$ & $\begin{array}{l}\text { Fujian Normal } \\
\text { University }\end{array}$ \\
\hline Ermakova E.V. & $\begin{array}{l}\text { Trade Credit } \\
\text { Management in } \\
\text { Wholesale Companies } \\
\text { based on Statistical } \\
\text { Models }\end{array}$ & 2018 & $\begin{array}{l}\text { Toptancı şirketlerde istatistiki yöntemler } \\
\text { kullanılarak tedarikçi kredi riskinin analiz } \\
\text { edilmektedir. }\end{array}$ & Statistika Ekonomika \\
\hline Werner 0. & $\begin{array}{l}\text { Management of trade } \\
\text { credit by small and } \\
\text { medium sizedenterprises }\end{array}$ & 2018 & $\begin{array}{l}\text { Güney Afrika'da KOBi statüsündeki şirketlerin } \\
\text { kredi riskini yönetme konusundaki } \\
\text { uygulamalarını araştıran bir saha çalışması } \\
\text { yapılmıştır. }\end{array}$ & $\begin{array}{l}\text { journal of Economic } \\
\text { and Financial } \\
\text { Services }\end{array}$ \\
\hline Michalski G. & $\begin{array}{l}\text { A Portfolio management } \\
\text { Approach in Accounts } \\
\text { receivableManagement }\end{array}$ & 2008 & $\begin{array}{l}\text { Riskin yönetilmesinde tek bir müşteri } \\
\text { grubundan ziyade portföye ilişkin olarak } \\
\text { alınabilecekkredi risk kararların karşılaşılacak } \\
\text { riski azaltabileceği ve karlılığı arttırtacağı } \\
\text { sonucuna varılmıştır. }\end{array}$ & $\begin{array}{l}\text { South East European } \\
\text { Journal of } \\
\text { economics\&Business }\end{array}$ \\
\hline $\begin{array}{l}\text { Zainudin, N., \& } \\
\text { Regupathi, A. }\end{array}$ & $\begin{array}{l}\text { Manufacturing SMES' } \\
\text { Credit Collection Period } \\
\text { and Its Determinants: } \\
\text { Some Evidence From } \\
\text { Malaysia }\end{array}$ & 2010 & $\begin{array}{l}\text { Alacak tahsilat süresinin şirketler arasında ne } \\
\text { şekilde farklılaştığını ölçmek amacıyla yapılan } \\
\text { çalışmadaşirketin büyüklüğünün, likiditesinin } \\
\text { ve şirket karlılığının farklılık yarattığı ve alt } \\
\text { sektörlere değişkenlik gösterdiği sonucuna } \\
\text { varılmıştır. }\end{array}$ & $\begin{array}{l}\text { Folia Oeconomica } \\
\text { Stetinensia }\end{array}$ \\
\hline
\end{tabular}

\begin{tabular}{|l|l|c|l|l|}
\hline Yazar & Makalenin Adı & $\begin{array}{c}\text { Yayınlandığı } \\
\text { Yıl }\end{array}$ & Makale konusu & $\begin{array}{l}\text { Yayınlandığı } \\
\text { Akademik } \\
\text { Dergi }\end{array}$ \\
\hline \multicolumn{2}{|l|}{ Kredi Riskinin Transferiyle İlgili Çalışmalar } \\
\hline $\begin{array}{l}\text { Baressa } \\
\text { S.Sinissa B }\end{array}$ & $\begin{array}{l}\text { Factoring : Alternative } \\
\text { Model of Financing }\end{array}$ & 2011 & $\begin{array}{l}\text { Faktoringin işleyişine değinilerek, kredi riski } \\
\text { yönetiminde faktoringin rol ve önemi incelenmektedir. }\end{array}$ & $\begin{array}{l}\text { UTMS Journal } \\
\text { of Economics }\end{array}$ \\
\hline $\begin{array}{l}\text { Auboin \& } \\
\text { Engemann }\end{array}$ & $\begin{array}{l}\text { Testing the Trade Credit } \\
\text { and Trade Link: } \\
\text { Evidence from Data on } \\
\text { Export Credit Insurance }\end{array}$ & 2014 & $\begin{array}{l}\text { Kredi sigortası tedarikçi kredisinin teminat altına } \\
\text { alınmasında önemli bir role sahiptir. Sigortalanmış } \\
\text { ihracat, ülke ihracatının artmasına destek olur }\end{array}$ & $\begin{array}{l}\text { Review of } \\
\text { World } \\
\text { Economics }\end{array}$ \\
\hline Egger V. \& Url & $\begin{array}{l}\text { Public Export Credit } \\
\text { Guarantees and Foreign } \\
\text { Trade Structure } \\
\text { Evidence from Austria }\end{array}$ & 2006 & $\begin{array}{l}\text { Ihracatta kredi sigortası desteği ihracatın artmasına } \\
\text { katkı sağlar }\end{array}$ & $\begin{array}{l}\text { The World } \\
\text { Economy }\end{array}$ \\
\hline
\end{tabular}




\begin{tabular}{|c|c|c|c|c|}
\hline $\begin{array}{l}\text { Summers B, } \\
\text { Wilson N. }\end{array}$ & $\begin{array}{l}\text { Trade Credit } \\
\text { Management and the } \\
\text { Decision to Use } \\
\text { Factoring : An Empirical } \\
\text { Study }\end{array}$ & 2000 & $\begin{array}{l}\text { Kredili satış yapan şirketlerin karşılaştıkları kredi riskini } \\
\text { yönetmeleri konusundaki sorumlulukları konusuna } \\
\text { değinilerek, risk yönetim faaliyetleri ile faktoringin } \\
\text { sunduğu hizmetler karşılaştırılmıştır. }\end{array}$ & $\begin{array}{l}\text { Journal of } \\
\text { Business } \\
\text { Finance } \\
\text { \&Accounting }\end{array}$ \\
\hline Klapper I. & $\begin{array}{l}\text { The Role of Factoring } \\
\text { for Financing Small and } \\
\text { Medium Enterprises }\end{array}$ & 2006 & Kredi riskinin yönetilmesinde faktoringin önemi & $\begin{array}{l}\text { Journal of } \\
\text { Banking } \\
\text { \&Finance }\end{array}$ \\
\hline $\begin{array}{l}\text { Aubin M , } \\
\text { Symthe H.,Teh } \\
\text { R. }\end{array}$ & $\begin{array}{l}\text { Supply Chain Finance } \\
\text { and SMEs: Evidence } \\
\text { from International } \\
\text { Factoring Data }\end{array}$ & 2016 & $\begin{array}{l}\text { Tedarikçi kredisinin teminat altına alınmasnda ve } \\
\text { ticari alacağın finansmanında faktoringin rol ve } \\
\text { önemine değinilerek, ticaretin gelişimine olan katkısı } \\
\text { değerlendirilmiştir. }\end{array}$ & $\begin{array}{l}\text { WTO } \\
\text { Working } \\
\text { Paper }\end{array}$ \\
\hline $\begin{array}{l}\text { Felbelmayr \& } \\
\text { Yalçin }\end{array}$ & $\begin{array}{l}\text { Export Credit } \\
\text { Guarantees and Export } \\
\text { Performance }\end{array}$ & 2010 & $\begin{array}{l}\text { Çalışmanın sonucuna göre, ihracatta kredi sigortası } \\
\text { desteği ihracatın artmasına katkı sağlar. }\end{array}$ & $\begin{array}{l}\text { The World } \\
\text { Economy }\end{array}$ \\
\hline
\end{tabular}

\subsection{Kredi Risk Yönetim Sürecinin Kurgulanması}

Risk yönetimi, kuruluşların stratejik yönetimlerinde merkezi bir rol oynar. Şirketlerin faaliyetleri sırasında ortaya çıkabilecek risklerin önceden tanımlanıp, değerlendirilmesini ve minimize edilmesini sağlayan tedbir ve uygulamaları içerir. Risk Yönetim Enstitüsü’ne göre risk yönetimi bir süreç şeklinde planlanmalıdır. Bu süreçte ilk adım şirketin stratejik hedeflerinin belirlenmesidir. Bu stratejik hedeflere uygun olarak faaliyetlerin yürütülmesi gereklidir. Faaaliyetlerin yürütülmesi sırasında karşılaşılan riskler tanımlanmalıdır. Bu nedenle, bir sonraki adım riskin değerlendirilmesine yönelik risk belirleme, tanımlama, analiz çalışmalarının yapılmasıdır. Riskin olma olasılığı ve şirkete olan muhtemel etkisi farklı risk gruplarına göre çeşitli risk ölçüm metodları ile analiz edilir. Elde edilen sonuçlar bir değerlendirmeye tabi tutularak, risklerin olma olasılığı ve etkisi bakımından sınıflandırılır. Değerlendirme sonuçlarına göre, riske karşılık olusturmak üzere bir risk yönetim stratejisi belirlenir. Bu stratejiler, kaçınma, riskin kontrol edilmesi ve risk finansmanı olarak belirlenmiştir. Riskin finansmanı, riskin sigortalama yoluyla diğer kuruluşlara transfer edilmesi veya riskin şirket tarafından üstlenilmesi yoluyla riski kendi kaynakları ile finanse etmesi anlamını taşır. Bir sonraki adım sürecin etkinliğinin izlenmesi ve şirketiçi geri bildirimlerin ve raporlamaların yapılmasıdır. (Institute of Risk Management) Rejda, risk yönetim sürecindeki adımları sırasıyla risk belirleme, risk analizi, risk yönetim stratejilerine karar verme ve risk izleme olarak belirlemiştir. Risk yönetim stratejileri ise kaçınma, riskin önlenmesi veya azaltılmasına yönelik kontrol, riskin üstlenilmesi ve risk transferi kararlarından oluşmaktadır. (Rejda \& McNamara, 2017) Risk yönetiminin sırasıyla bu faaliyetleri içeren bir süreçte yönetilmesi, kredi risk yönetiminin de benzer şekilde çeşitli adımları olan bir süreçte yönetilmesi gerektiğine işaret etmektedir. Kredi risk yönetiminde süreç, kredi riskinin oluşumuna sebep olacak risk faktörlerinin belirlenmesi ile başlar. Müşteri kabul kriterlerinin belirlenmesinde ve çalışma imkanlarının gözden geçirilmesinde bilgi alma faaliyetleri önemli bir rol oynar. Riskin tahminlenmesine yönelik kredi riskinin analiz edilmesi gerekir. Riskin önlenmesi, azaltılması için yapılması gereken faaliyetleri içerir. Riski üstlenme veya transfer etme konusunda kararlar almayı gerektirir. Risk izleme ise sürecin son aşamasını oluşturan ve geri bildirimler yoluyla sürecin iyileştirilmesine katkı sağlayan bir gözden geçirme ve iyileştirme faaliyeti olarak süreçte yer alır. Aşağıda, genel risk yönetim sürecinin her bir adımı açıklanarak, kredi riskinin yönetilmesine yönelik olarak süreç kurgulanmıştır. Şekil 1'de anlatılanların bir özeti yer almaktadır.

\section{Şekil 1: Kredi Risk Yönetim Süreci}
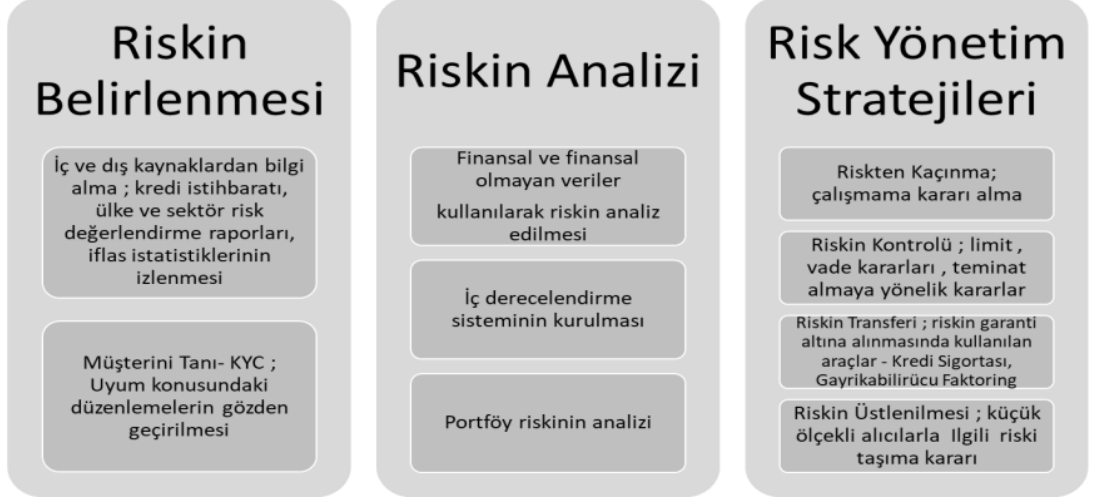

\section{Risk İzleme}

Tahsilatın izlenmesi, erken uyarı sistemlerinin kurulması Alacak yaşlandırması takibi tahsil süresinin takibi Risk değerlendirme sürecinin gozden gecirilmesi ; bigi alm
faaliyetlerinin ve risk analizi yöntemlerinin gözden geçirilmesi Risk yönetim stratejilerinin gözden geçirilmesi

Tahsilat yöntemlerinin gözden geçirilmesi 


\subsubsection{Risk Belirleme}

Risk belirleme faaliyeti, kuruluşun maruz kaldığı risklerin ve belirsizliklerin tanımlanmasına yönelik bilgi toplama faaliyetlerinden oluşur. Riske sebebiyet verebilecek faktörlerin belirlenmesine yönelik şirketiçi veya şirket dışı kaynaklara başvurularak, uzman kuruluşların veya kişilerin bilgi ve tecrübelerinden yararlanılır.

Kredi riskinin belirlenmesinde kredi istihbaratı önemli rol oynar. Kredi istihbaratı, borçlunun ödeme kapasitesinin belirlenmesinde ihtiyaç duyulan bilgi ve belgelerin elde edilmesine yönelik bilgi toplama faaliyetidir. Bilgi toplama aşamasında iç ve dış kaynaklardan yararlanılır. İç kaynaklar müşteri ziyaretlerinde elde edilen bilgi ve belgelerden oluşur. Şirketin tesis, fabrika ve depoları ziyaret edilerek, üretim ve satış süreci hakkında kapsamlı bilgi elde edilir. Şirket faaliyetleri incelenir. Şirketin risklerini yönetme becerisi değerlendirilir. Ileriye dönük stratejilerinin tesbiti için üst düzey görüşmeler yapılır. Yönetim kabiliyetinin değerlendirilmesine yönelik iş geliştirme toplantıları düzenlenir. Şirket yöneticilerinin ahlaki tutum ve davranışlarının değerlendirilmesine yönelik bir kanaat oluşturulur. Elde edilen bilgilerin tam olması ve müşterinin hiç bir şüpheye yer vermeyecek şekilde bilgi ve belge sunması değerlendirmede şeffaflı̆̆ın bir göstergesi olarak dikkate alınır. Müşterini tanı (KYC-Know Your Customer) prensipleri doğrultusunda şirketin her türlü sicil kaydı bilgileri, adresi, telefonu, kuruluş tarihi, ortaklık yapısı, sicilde kayıtlı faaliyet konusu, çalıştığı bankaları kayıt altına alınır. Bu ziyaretlerde müşteri adayının finansal gücünün tespitine yönelik finansal tabloları talep edilir. Devam eden davaların olup olmadığı sorgulanır. Dış kaynaklar ise, yayınlanmış raporlar, web sitelerinden elde edilen bilgiler, yerel ve uluslararası kuruluşların derlediği raporlardan oluşur. Uluslararası kredi derecelendirme kuruluşlarının (S\&P, Moody's, Fitch) yayınladığı ülke ve sektör raporları incelenir. Bu kuruluşlar, şirketlerin kredi değerliliğinin göstergesi olarak kredi derecelendirme notu yayınlarlar. Kredi derecelendirme notu şirketin risk derecesini gösterir. Dun \&Bradstreet (D\&B) gibi global ölçekte faaliyet gösteren kredi istihbarat kuruluşlarından (credit information bureaus) şirketin finansal durumu ve ödeme geçmişi hakkında bilgi alınır. (Bartels \& Hirt, 2001) Global ölçekte faaliyet gösteren kredi sigortası kuruluşlarının alıcı limit kararları da şirketler için önemli bir bilgi kaynağıdır. Bu limit kararlarının ekinde alııının finansal performansına ilişkin bilgiler yer alır. Bu kuruluşlar aynı zamanda belirli dönemlerde alıcının bulunduğu ülkeye ve sektöre ilişkin risk değerlendirme raporları yayınlarlar. Bunun yanısıra ülkeler ve sektörler bazında ödeme vadelerindeki değişimleri takip ederler. Riskin değerlendirme sürecinde ve riskin izlenmesinde bu bilgilerin dikkate alınması gerekir. Kredi sigortası kuruluşları ülkemizde de faaliyet göstermektedirler. (Euler Hermes;Coface Global;Group Atradius). D\&B, ülkemizdeki faaliyetlerini işbirliği anlaşması dahilinde CRIF üzerinden sürdürmektedir. (CRIF ). Bu kuruluşların yanısıra ülkemizde finansal kuruluşlara veri toplama ve paylaşım hizmeti vermek üzere Kredi Kayıt Bürosu (KKB) kurulmuştur. T.C.M.B nezdindeki Risk Santralizasyon Merkezi öncelikle Türkiye Bankalar Birliği Risk Merkezine devredilmiş ve daha sonra KKB bu hizmeti üstlenmiştir. Kredi Kayıt Bürosu çek raporu, risk raporu ve elektronik rapor sistemi ile yalnız finansal kuruluşlara değil, aynı zamanda bireylere ve reel sektöre yönelik hizmetler sunmaya başlamıştır. (Kredi Kayıt Bürosı)

Müşteri ile çalışma kararının verilmesinde, özellikle uluslararası ticarette müşterini tanı (Know Your Customer - KYC) kavramı gün geçtikçe önem kazanmaktadır. Şirketin yasal uyum ( legal compliance ) kapsamında faaliyetlerini sürdürüp sürdürmediği incelenir. Yasal uyum'un icine yolsuzluk ve karapara aklamayı önleme, rüşvet ve vergi kaçakçılığını önleme, suç örgütlerine giden fonların engellenmesi, uluslararası yaptırım ve ambargolar gibi takip edilmesi gereken konular girmektedir. Uluslararası ticaret yapan firmaların özellikle bu konularda bilgi ve deneyimli olmasi doğabilecek yasal riskleri önleyecektir. Bu riskler sadece milyonlarca dolarlık cezaları değil ayni zamanda şirket üst duzey yetkililerinin hapis cezası alması gibi konuları da kapsamaktadir. Dünya üzerindeki 180 ülkede algılanan yolsuzluk (corruption perception index) endeksini hesaplayan ve bu konuda uluslarası kabul gören "Transparency International'in" 2019 yılı raporu firmalara bulundukları veya girmeyi hedefledikleri pazarlarda karşılaşacakları risklerin olma olasılığı üzerine fikir vermektedir. (2019 CPI Report) 0-100 puan arasinda puan verilen 180 ulkenin 2019 yili ortalamasi 43'dur. 100 puanin en temiz ekonomileri temsil ettiği düşünüldüğünde 50 puanın altındaki bu ortalama şirketlere risk konusunda daha geniş ve yapısal bakmanin gerekliliğini ispatlamaktadir. Yasal uyum konusu müşteri riskinin değerlendirilmesinde, kredi kontrol prosedürleri arasında yer alan son derece önemli bir konudur. Bir cok şirket yönetimi, kendi şirketinin yasalara ve uluslararasi ticaret kurallarina uydugu sürece, bu risklerden kaçınabileceği gibi yanlış veya eksik bir kanıya sahiptir. Oysa, firmalarin birlikte calistiklari diger firmalarin da bu uluslararasi yasa ve kurallara uyduğuna dair bir kontrol mekanizmasının geliştirilmesi gereklidir. Özellikle A.B.D, AB ülkeleri ve İngiliz yasaları (The United States Department of Justice Foreign Corrupt Practices Act), (EU Global Sanctions Guide), (Bribery Act 2010), (OFAC Sanctions List) satıcı firmalarin bu kontrol mekanizmasini aktif olarak uygulaması ve herhangi bir denetim sırasında yapılan çalışmaları gösterebilmesinin satıcı sorumluluğu olduğunu açık ve net göstermektedir. ABD, ozellikle bu suçlara karışmış kişi ve kuruluşların listesini Hazine Departmanina ait resmi web sitesinde yayınlamaktadır. (SDN) Uluslararasi ticaret yapan firmaların bu gibi kaynakları devamlı kontrol etmesi beklenir. Bu bilgileri konsolide edip raporlayan firmalar bulunmaktadir. Refinitiv firmasi da bunlardan biridir. (Refinitiv) Bu firmanin gelistirdigi "WorldCheck Screening" platformu sayesinde satıc firmaların birlikte çalıştıkları müşterşlerinin , bağlı kuruluşların ve şirket ortaklarının herhangi bir risk grubuna dahil olup olmadıklarını kontrol etme imkanı bulunmaktadır. (World Check KYC Screening) Bu platformda listelenen kisi ve kurumlar ile ilgili paylasilan bilgilerin dikkatle gozden gecirilmesi gerekmektedir. Ozellikle kara para aklama (Anti Money 
Laundering- $\mathrm{AML}$ ), terorizm ve diğer suçlar, rekabet hukukuna aykırılık, rüşvet gibi konular nedeniyle listeye dahil edilmiş firma ve/veya firma ortaklari ile çalışılmaması şirketin ileride karşılaşabileceği riskleri önleyecektir. Satış ve kredi kontrol departmanları olasi bir riskinin tahmin edilmesinde önemli bir sorumluluğa sahiptirler. Uyum konusunun karşılaşılan örnek vakalar ile incelenmesi, bu konuda şirketlere yönelik eğitimlerin yapılması bu riskin önlenmesi için ornek vakalar ile ilgili olarak duzenli egitim verilmesi sirketlerin lehine olacaktir. Şirketiçi eğitimlerin yansıra, çevrimiçi bilgi ve broşürlere günümüzde cok rahat erisilebilmektedir. Bu konuda düzenli yayın yapan kuruluşların web sitelerinden bilgi almak mümkündür.

\subsubsection{Risk Analizi}

Şirketlerin maruz kalabilecekleri risklerin, olma olasılıkları ve şirkete olan etkileri bakımından analiz edilmesi, ölçümlenmesi risk yönetim sürecindeki 2. aşamadır. Riskin tahminlenmesine yönelik yapılan bu çalışmada çeşitli ölçümleme yöntemlerinden yararlanıı. Şirketler tarafından kullanılan bazı risk ölçüm araçları duyarlııı analizleri, Monte Carlo simulasyonu, regresyon analizi , riske maruz değer hesaplamaları gibi yöntemlerden oluşur.

Kredi riskinin analizi, kredi riskine girilecek alıcıların ödeme kapasitelerinin belirlenmesine yönelik yapılır. Finansal kuruluşlarda olduğu gibi , kredi riskinin analizinde, risk belirleme safhasında elde edilen bilgi ve belgeler dikkate alınır. Ülke ve sektör riskine ilişkin değerlendirmeler yapılır. Şirketin faaliyetleri incelenerek şirket faaliyetlerinin sürdürülmesini engelleyebilecek dış ve iç riskler analiz edilir. Şirketin bu riskleri yönetme becerisi değerlendirmeye tabi tutulur. Finansal olmayan verilerle yapılan bu analizin yanısıra şirketin finansal tabloları üzerinden bir inceleme yapılır. Bu analizde, bilanço ve gelir tablosu yatay ve dikey analize tabi tutulur. Rasyo analizi yapılır. Fon akış ve nakit akış tabloları oluşturularak şirketin fon ve nakit yaratma kabiliyeti analiz edilir. Şirket analizde hangi yöntemleri kullanacağını kendisi belirler. Finansal tablolardaki dönemsel değişimler incelenir. Kredi riskinin analizinde dış çevre risklerinden başlayarak sırasıyla şirketin faaliyette bulunduğu sektöre ilişkin riskler ve daha sonra şirkete özgü riskler analiz edilir. (Bkz. Şekil 2) (Edwards, 2010)

Şekil 2: Kredi Riskinin Analizinde Adımlar

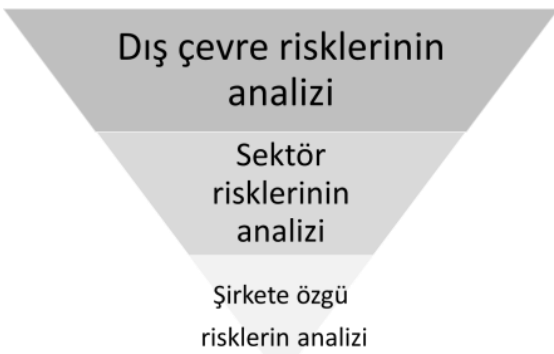

Bankacılık sektöründe, kredi riskinin analizinde geleneksel olarak $5 \mathrm{~K}$ formülü olarak bilinen yöntem kullanılır. Bu formüldeki her bir harf, kredi riskinin analizinde yapılması gereken faaliyetleri tanımlar. Bankacılıkta kredi tahsis kararları bu yönteme göre yapılır. Şirket riskinin analizinde de bu formülden yararlanmak mümkündür. Aşağıda, $5 \mathrm{~K}$ formülü hakkında kısa bilgilere yer verilmektedir. ( O'Connelly, 2007)

Karakter (Character)- Karakter, finansal ödeme gücünden bağımsız olarak şirketin borcunu ödeme konusundaki ahlaki tutumu ve dürüst iş yapma koşullarına uyup uymayacağının bir göstergesidir. Bu göstergenin ölçümü, yönetim risklerinin ölçülmesi ile mümkündür.

Kapasite (Capacity)- Kapasite, borçlunun borcunu ödeyebilme kabiliyetidir. Kredi analiz sürecinde kalitatif ve kantitaif analiz sonucunda borçlunun borcunu ödeyebilme kapasitesi hakkında bir sonuca varılır.

Sermaye (Capital)- Borçlunun sermayesi finansal gücünü gösteren unsurlardan biri olarak önem kazanmaktadır.

Koşullar (Conditions)- Borçlunun faaliyet gösterdiği sektörün yapısal özelliklerine bağlı olarak ortaya çıkan risklerle makroekonomik koşulların ve diğer diğer dış çevre koşullarının yapılan incelemede dikkate alınması gerekmektedir.

Teminatlar (Collateral)- Birincil teminat, geri ödeme kaynağı her zaman nakit akışıdır. Diğer ipotek, rehin vb tüm teminatlar ikincil teminatlar olarak değerlendirmede dikkate alınır. Borçludan alınan teminatların değeri, kredi borcunun altında kalmamalıdır. Teminatlar da kendi içerisinde güvenilirlik ve likidite açısından bir değerlendirmeye tabi tutulur.

Portföyde yer alan alııların çok sayıda küçük alıcılardan oluşması durumunda skorlama yöntemlerine başvurulabileceği gibi portföyün tümünün değerlendirilmesinde, sektörler ve alıcılar bazında yoğunlaşma riskinin veya korelasyon etkisinin hesaplanmasında, bütün olarak toplamda ne kadar riske katlanılabileceği gibi portföye ilişkin değerlendirmelerde istatistik yardımıyla ölçümlemeler yapılabilir. Genellikle finansal kuruluşlar ve çok sayıda alıcısı olan büyük şirketler portföyde yer alan 
müşterilerinin bulundukları sektörleri de dikkate alarak alt gruplandırmalar yapabilirler ve kredi riskini bu alt gruplandırmalara göre portföy bazında değerlendirmek isteyebilirler. Olası kredi riskinin hesaplanması, riske karşılık ayırma ve sermaye tahsis etme konusunda belirleyici rol oynar. (Joseph, 2013)

\subsubsection{Risk Yönetim Stratejileri}

Risk değerleme sonucuna göre riske nasıl karşılık verileceği belirlenir. Riske verilecek karşılık, risk yönetim stratejileri olarak da adlandırılır. Risk yönetim stratejileri, olma olasılığı ve etkisi yüksek riskler için riskten kaçınmayı, olma olasılığı düşük ancak etkisi yüksek riskler için riski transfer etmeyi, olma olasılığı ve etkisi düşük sayılabilecek riskler için riskin üstlenebileceğini ve olma olma olasılığı yüksek ve fakat etkisi düşük riskler için ise riskin azaltılması veya önlenmesi yöntemlerinden birinin seçilmesini gerekli kılar. Bu stratejilerin bazıları birarada da kullanılabilir. Özellikle sigortanın bir risk transfer aracı olarak kullanılması durumunda, riskin sigorta şirketi tarafından üstlenilmesi için, riski azaltma veya önleme konusunda şirketin sigortalanmamışçasına hareket etmesi bir gerekliliktir. Şekil 2'de risk yönetim matriksi yer almaktadır. (Rejda \& McNamara, 2017) Aşağıda risk yönetim stratejilerine kısaca değinilerek , kredi riskinin yönetilmesinde stratejiler tanımlanmıştır.

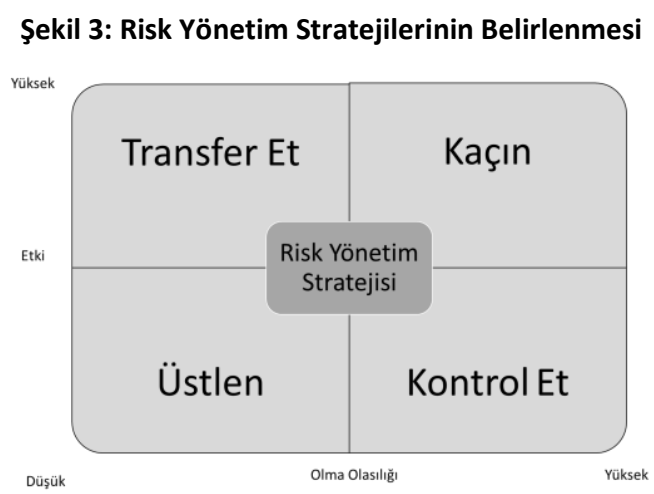

\subsubsection{Riskin Kontrolü}

Riskin önlenmesi ve azaltılmasına yönelik çalışmalar riskin kontrol edilmesine yönelik çalışmalardır. Risk önleme, riskin olma olasılığını azaltma amacıyla yapılır. Risk azaltımında ise riskin etkisinin azaltılması hedeflenir. Risk önleme ve azaltım yöntemleri risk türlerine göre farklılık gösterir. Faaliyet risklerinden biri olan yangın riskinin önlenmesinde yangın riskine sebebiyet verecek yanıcı maddelerin ortadan kaldırılması bir risk önleme faaliyeti iken, yangın riskinin azaltılmasında ise örneğin su püskürtücülerinin kullanılması risk azaltımına bir örnek oluşturabilir. Birinci örnekte, riskin olma olasılığı önlenirken, ikinci örnekte riskin oluşması halinde zararın daha az olması hedeflenmektedir. Döviz riski ile karşılaşmak istemeyen şirket ihracata yönelir. Döviz riskinin azaltılmasında pozisyon limitleri belirlenebilir.

Alıcı firmalara tanınan kredi limiti kararları kredi riskinin kontrol edilmesinde önemli bir rol oynar. Şirket bu limite kadar risk alır. Riskli görülen firmalara daha düşük kredi limitleri tanımlanabilir. Belirli dönemlerde yapılan değerlendirmelerde kredi limiti kararları da gözden geçirilir. Kredi limitinin iptali ya da azaltım kararının verilmesi kredi riskinin kontrolüne yönelik olarak yapılır. (Salek , 2005) Şirket her alıcı için bir kredi vadesi belirler. Kredi vadesinin riskli görülen müşteri için azaltılması bir diğer risk kontrol yöntemidir. Riskli görülen bir müşteri için daha düşük bir kredi limiti ve aynı kredi vadesi ile çalışma kararı alınabileceği gibi; daha düşük bir kredi limiti ile daha düşük bir vadede çalışma yapılması konusunda bir karara varılabilir. Teminatların arttırıması veya ilave teminatların alınması riskin gerçekleşmesi durumunda katlanılan zarar tutarını azaltacaktır. (Joseph, 2013) ìhracat müşterilerine yönelik olarak yapılan satışlarda, riskin değerlendirilmesi sonrasında, ihracatçı açısından daha güvenilir ödeme şekilleri ile çalışma kararı alınabilir. Ödeme geçmişinde sıkıntılar olan bir müşteri ile peşin ödeme veya akreditif karşılığı çalışma kararı alınabilir. Düşük bir kredi limiti ile çalışılması düşünülen müşterilerde ürünün maliyetini oluşturan kısım için peşin ödemeli satış yapılırken, kar marjı için ise bir miktar kredi açılabilir. Kredi limitinin iptali yerine, peşin ödeme ve açık hesap ödeme şekli bir arada yürütülebilir. (Bragg, 2011) Portföyde yer alan alıcılara tanınan kredi limitlerinin şirketlerin bulunduğu ülkeler ve sektörler itibarıyla gözden geçirilmesi yoluyla, kredi limitlerinin farklı ülke ve sektörlerde faaliyet gösteren alıcılara dağıtılması sağlanır. Böylelikle, yoğunlaşma riskinin önlenmesine çalışlır. (Joseph, 2013)

\subsubsection{Riskten Kaçınma}

Kuruluşun riskli işlemleri içeren faaliyetlerden kaçınmayı tercih etmesidir. Kaçınma, riskin olma olasılı̆̆ının ve şirkete etkisinin yüksek olduğunun hesaplanabildiği durumlarda kullanılan bir risk yönetim stratejisidir. Örneğin, sel ya da deprem riskinin yüksek olduğu yerlere tesis yapılmaması kararı bir kaçınma stratejisidir. Şirket örneğin ürettiği ürünün 3. Şahıslara zarar 
vereceini öngörüyorsa, bu ürünü üretmekten vazgeçebilir. Hisse senedi yatırımından kaynaklanan fiyat değişim riskini almak istemeyen yatırımcı hisse senedi yatırım yapmaktan kaçınabilir. Ülke riskini almak istemeyen bir firma, istikrarlı bir siyasi ve ekonomik yapısı olmayan ülkeleri pazar olarak seçmeyecektir.

Şirket kredi riskine maruz kalmamak için, potansiyel müşteri ile çalışmama kararı alabilir. Risk değerleme faaliyetleri sonucunda belirli ülkelerde yerleşik alııılarla veya belirli sektörlerde faaliyet gösteren alıcılarla çalışmama kararı alabilir. Şirketin geçmiş ödeme performansında sorun varsa şirketle çalışılmama kararı alınabilir. Değerleme sonuçlarına göre teminat alınmasına karar verilmesi durumunda şirket yeterli teminatı veremezse veya şirketin yasal yükümlülüklerine uymamaması sonucu şirkete açılan davalar sözkonusuysa, şirket uyum kriterlerini yerine getiremiyorsa, şirketle çalışmama kararı alınır . (Joseph, 2013)

\subsubsection{Riskin Transferi}

Riskten kaynaklanabilecek zararın bir kuruluşa aktarılması veya bir kuruluşla paylaşılması riskin transfer edilmesi olarak tanımlanır. Örneğin deprem, yangın, sel, hırsızlık gibi mal varlığı risklerine karşı yaptıılan sigortalar, riskin gerçekleşmesi halinde oluşan zararın sigorta şirketi tarafından karşılanması anlamına gelmektedir. Sigorta bir risk transfer aracıdır. Döviz cinsinden alınan bir krediden kaynaklanan döviz kuru riski türev piyasalarda alınacak karşı pozisyon ile tamamen veya kısmen hedge edilebilir. Böylece, kur değişiminden kaynaklanabilecek zarar karşı tarafa transfer edildiğinden şirket kur değişimlerinden etkilenmez.

Uluslararası ticarette kullanılan akreditifler ve benzeri banka garantileri, bankanın ithalatçı lehine ihracatçıya sunduğu garantilerdir. Yurtiçi ticarette, borçludan elde edilen teminatlar riskin azaltılmasına yardımcı olur. Bununla birlikte risk transferi riskin bir 3. kuruluşa transfer edilmesi anlamını taşıdığından, bir banka garantisinin söz konusu olmadığı açık hesap ticarette kredi sigortası (credit insurance) ve gayrikabilirücu factoring ( without recourse factoring) bu amaca hizmet etmektedir. Kredi sigortası bir sigorta ürünüdür ve diğer sigortalarda olduğu gibi bir güvence hizmeti sunar. Kredi sigortası ile şirket, alııı hakkında kredi istihbaratı elde eder. Sigorta şirketi alıcıya yönelik olarak bir kredi riski değerlemesi yapar ve riski de buna göre garanti altına alır. Sigorta şirketinin vermis olduğu kredi limiti kararları doğrultusunda şirket mal ve hizmet sevkiyatını gerçekleştirir. Şirketin kendi risk değerleme faaliyeti sonucunda vermis olduğu kredi limiti kararları, sigorta şirketinin vermis olduğu kararlar ile birlikte gözden geçirilir. Limit verilmeyen müşterilerde riskten kaçınma yoluna gidebileceği gibi, riski kontrol etmek bakımından şirket önlem alma veya riski azaltma amacıyla kendi limit, vade ve teminat alma kararlarını gözden geçirir. Sigorta şirketinin belirli dönemlerde yaptığı değerlendirmede limit iptaline veya azaltımına gitmesi durumunda, şirket de o alıcıya ilişkin kredi koşullarını gözden geçirir. Kredi sigortası şirketinin sunduğu tahsilat hizmetlerinden yararlanılır. Kredi sigortasının sunduğu garanti ve hizmetler bakımından şirketlerin kredi riski yönetim sürecindeki rol ve önemi aşağıdaki Şekil 3 'de özetlenmektedir) (Riestra, 2003)

\section{Şekil 4: Kredi Sigortasının Kredi Risk Yönetim Sürecindeki Rolü}

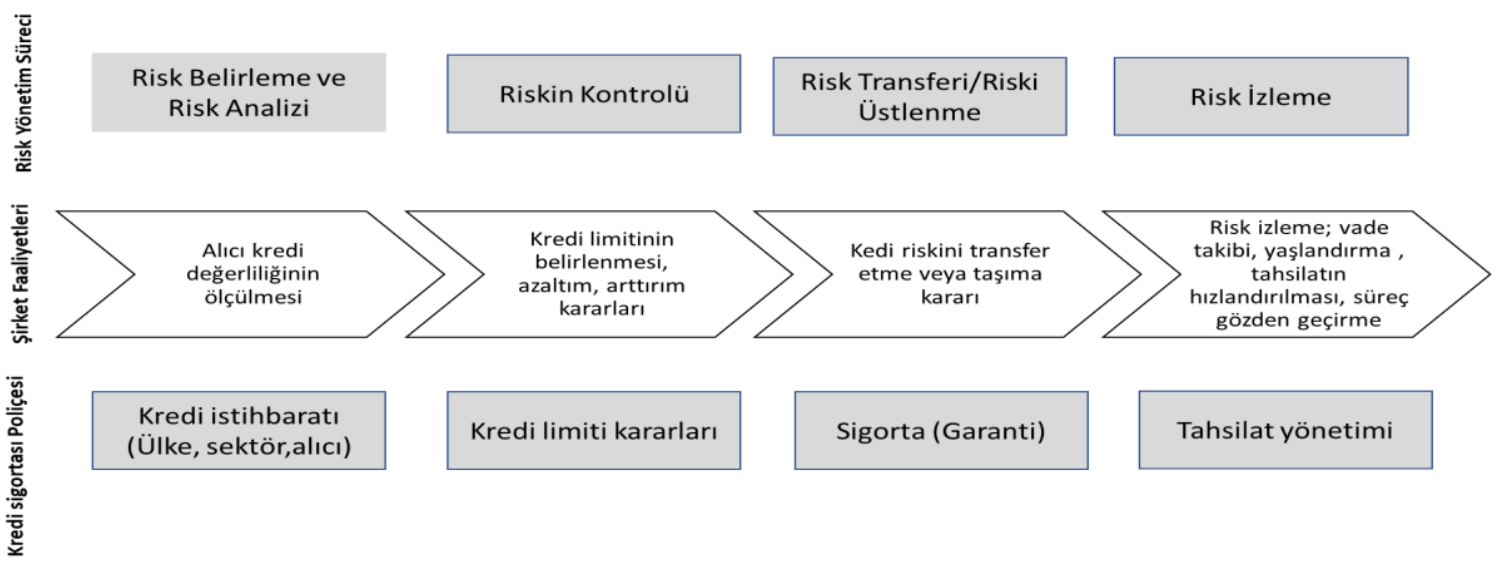

\subsubsection{Riskin Üstlenilmesi}

Şirketin riski transfer etmemesi, hiç bir önlem almaması ve riskin gerçekleşmesinden kaynaklanabilecek zararı kabullenmesi riskin üstlenilmesi veya taşınması kararıdır. Bu karar, riskin olma olasılığı düşükse veya riskin etkisi de ihmal edilebilir düzeyde ise bir strateji olarak seçilebilir. Riski önleme ve azaltma faaliyetleri için yapılan harcamaların veya riskin transfer edilmesi için ödenecek prim ve komisyon gibi giderlerin riske katlanma maliyetinden yüksek olması durumunda da riski taşıma kararı alınabilir. Riskin üstlenilmesi durumunda, riskin maliyetine katlanılır. 
Şirket belirli bir alacak seviyesinin altında kalan borçlular için teminat almama kararı alabilir. Riski sigortalatmayabilir. Bu durumda kredi riski şirket tarafından üstlenilir. Burada gösterge, şirketin bugüne kadar taşıdığı şüpheli alacakların toplam alacağa oranı ve bu vakaların sayısıdır.

\subsubsection{Risk İzleme}

Risk komitesi veya risk yönetimi birimi, şirketin karşılaşı̆̆ı̆ı risklerin gelişimini izlemek ve riske karşılık vermek üzere seçilen risk yönetim stratejilerinin etkinliğini takip etmek zorundadır. Bu çalışmada tüm risk yönetim süreci gözden geçirilir ve gerekli iyileştirme kararları alınır. Şirketler, maruz kaldıkları riskleri tanımlamak, ölçebilmek ve gelişmelerin zamanında raporlanmasını sağlamak amacıyla gerekli bilgi sistem donanımlarını kurmak ve bu sistemlerin düzenli işleyiş̧ini gözetmekten sorumludurlar. Risk yönetimi sürecinin etkin bir şekilde izlenebilmesi ve geliştirilmesi, önerilerin oluşturulabilmesi için her adımın uygun bir şekilde belgelenerek kayıt altına alınması gerekmektedir. Varsayımların, yöntemlerin, veri kaynaklarının, alınan sonuçların ve alınan tüm kararların sebepleri ile belgelenmesi gerekmektedir.

İzleme faaliyeti, borcun vadesinde hesaba tahsilinin takibi ile sınırlı değildir. Tahsilatın gecikmesine ilişkin erken uyarı sinyallerinin dikkate alınması gerekir. Alacak yaşlandırmasının yapılması, ortalama tahsilat sürelerinin dönemsel olarak incelenmesi, gecikmiş ödemelerin izlenmesi, limit aşımlarının yapılıp yapılmadığına bakılması, risk limit kullanım oranlarının gözden geçirilmesi, teminat şartlarına uyulup uyulmadığı, teminatın riski karşılayıp karşılamadığı riske ilişkin izleme faaliyetleri arasındadır. Nakit akışını etkilemesi bakımından alacakların zamanında tahsil edilebilmesi şirketin en önemli anahtar performans göstergelerinden (key performance indicator - KPI) biridir. Ortalama tahsilat süresinin takibi (DSO-days sales outstanding), gerçek tahsilatın ne zaman yapıldığı, varsa gecikmeli ödemeler ve tahsil edilemeyen alacakların kontrolü şirketlerde kredi riskinin yönetilmesine ilişkin performansın ölçümüne ilişkin anahtar göstergelerdir. İzleme faaliyeti aynı zamanda, risk yönetim sürecindeki tüm faaliyetlerin etkinliğinin de sorgulanması anlamını taşır. Müşterini tanı- KYC kapsamında yapılan çalışmalar gözden geçirilir. (Joseph, 2013) Risk transferine başvurulup başvurulmadığına bakıır. Örneğin kredi sigortasından yararlanılmışsa, sigorta şirketinin vermis olduğu kredi limitinin riski karşılama durumuna bakılır. Tahsilat yöntemlerinin etkinliği sorgulanır. İzleme faaliyeti sürecin her aşamasında yapılan faaliyetlerin gözden geçirilerek, sürecin iyileştirilmesi konusunda önerilerin getirilmesine ve gerekli iyileştirilmelerin yapılmasına yönelik olmalıdır.

COVID-19 krizi sonrasında finansal kuruluşlar kredi riskini yönetmek konusunda farklı bir bakış açısına sahip olmuşlardır. Krizin ulusal ve bölge ekonomileri üzerindeki etkilerinin anlaşılması, sektörler ve alt sektörler bazındaki etkilerin analiz edilmesi, aynı sektörde veya alt sektörde faaliyet gösteren şirketlerin kredi değerliliği arasındaki farklılıkların sorgulanması gittikçe daha önemli hale gelmeye başlamıştır. Özellikle talep şoklarının şirketler üzerindeki etkilerinin analiz edilmesi, şirketlerin iş modellerinin sorgulanması ve risk karşısında dayanıklılı̆ın tespit edilmesi analizde dikkat edilmesi gereken konular arasında yer almaya başlamıştır. Gerçek zamanlı bilgiye erişim, risk değerlendirmede ve riskin izlenmesinde kritik hale gelmiştir. (Mc.Kinsey \& Company) Şirketler de benzer şekilde, gerçek zamanlı veriler ile değerlendirme yapmaya özen göstermelidirler. Risk değerlendirme çalışmalarında güncel verilerin kullanılması riskin önlenmesine yönelik olarak yapılmalıdır. Gerçek zamanlı bilgiye erişimin sağlanması, tahsilat konusunda şirketin erken harekete geçebilme kabiliyetini arttırır. COVID-19 etkisi ülkelere ve sektörlere göre değişmekle birlikte, en fazla KOBi'ler üzerinde gözlemlenmiştir. Araştırmalara göre, bazı ülkelerde KOBi'ler daha yüksek bir satış kaybı ile karşılaşmışlardır. Bu durum, temerrüt riskinin artacağına yönelik beklentileri arttırmaktadır. İhracata dayalı faaliyet gösteren bazı KOBi'ler, özellikle Kore ve Japonya'da faaliyet gösteren şirketler, tedarik zincirindeki aksamalara maruz kalmışlardır. Üretimin aksaması satış kayıplarına yol açmıştır. Şirketlerin kredi değerliliğinin güncel bir şekilde izlenmesi son derece önemli hale gelmiştir. (S\&P Global Market Intelligence)

\section{SONUÇ}

Risk yönetimi, şirketlerin hedeflerine ulaşmasını engelleyen risklerin belirlenerek minimize edilmesine yönelik aksiyonları içerir. Risk yönetiminin temel rolü şirket sahipleri, çalışanlar, kreditörler ve tedarikçiler dahil tüm paydaşlara şirketin karşılaştığı risklerin doğru yönetildiğine ilişkin bir güvence sağlamaktır. Kısa vadede satışların ve karlılığın arttırılması, uzun vadede ise şirket değerinin artması hedeflenir. Kredi riski şirketin yönetmek zorunda olduğu finansal risklerden biridir. Ticari alacakların şirket bilançosundaki payı düşünüldüğünde, tahsil edilemeyen alacaklardaki artış şirketlerin varlığını sürdüremeyecek boyutta büyük zararla karşılaşmasına yol açar. Kredi riski yönetiminde hedeflenen şirketin karlı ve sürdürülebilir bir müşteri portföyü ile çalışmasıdır. Kredi riski yönetimi bir süreç olarak ele alındığında kredi riskinin tespitine yönelik faaliyetler bu sürecin ilk aşamasını oluşturur. Şirketiçi ve şirketdışı risk oluşumuna sebep veren faktörlerin analiz edilmesi gerekir. Dış çevre riskleri, sektörel riskler değerlendirilerek, borçlunun finansal kapasitesinin analizine yönelik incelemeler yapılır. Veri toplama süreci "müşterini tanı" kriterleri ile birleştirilerek müşteri seçim kriterleri oluşturulur. Bu kriterler belirli dönemlerde gözden geçirilerek müşteri ile ilişkiyi sürdürüp sürdürmeme kararı alınır. Finansal ve finansal olmayan verilerin bir araya getirilerek değerlendirmenin yapıldığı bu sürecin sonunda kredilendirme kararı alınır. Değerlendirme sürecinde, riskin transferinde kredi sigortası gibi risk yönetim araçlarından yararlanılıp yararlanılmayacağı, kredi riskinin bir başka finansal kuruluşa örneğin faktoring kuruluşuna devredilip devredilmeyeceği, riskin hangi alacak seviyeleri için üstlenilebileceği gibi riskin yönetilmesine ilişkin stratejiler de gözönünde bulundurulur. Devam eden 
müşterilerde kredi limitlerinin azaltılması, arttırıması veya müşteri ile çalışmama kararının alınması, ek teminatların alınıp alınmayacağı gibi konular yönetim toplantılarında ele alınır. Ödeme davranışlarındaki gelişmeler izlenerek, dış kaynaklardan elde edilen bilgiler değerlendirilir. Şirketiçi ve şirket dışı tahsilat yöntemleri gözden geçirilir. Tahsilatın etkinliğine ilişkin öneriler dikkate alınır.

Kredi riski yönetiminin öne çıkmasının sebeplerinden biri 2008-2009 finansal krizi olmuştur. Global olarak tüm ülke ekonomilerinde daralma gözlemlenmiş, global ticarette düşüş meydana gelmiş, şirket iflaslarında ve ödeme problemlerinde artışlar gözlemlenmiştir. Global krizin etkisiyle artan iflaslar finansal kuruluşların risk alma iştahında azalma meydana getirmiş ve şirketler faaliyetlerini sürdürebilmek için kendi aralarında kredili ticarete yönelerek, riski üstlenmek yoluyla faaliyetlerini sürdürmeye çalışmışlardır. Finansal kriz sonrası görülen iyileşme, COViD - 19 kaynaklı pandemi etkisi ile yerini tekrar tüm ülkelerde görülen resesyona bırakmış, ekonomilerde ve ticarette talep ve arz kaynaklı küçülmeler yaşanmıştır. Bu etki 2009 finansal krizinin ekonomiler üzerinde yarattığı olumsuz etkiden çok daha büyük olmuş, özellikle tekstil sektörü, turizm sektörü, restoran ve otelcilik gibi bazı sektörlerde ciddi satış ve kar kayıpları yaşanmıştır. Tedarik süreçlerinde kesinti yaratan bu riskin tüm tedarik zincirindeki etkisi geciken ödemeler ve tahsilat problemleri ve artan iflaslar şeklinde ortaya çıkmıştır. Şirketlerde, işletme sermayesi yönetimi daha önemli hale gelmiş, alacak tahsilini hızlandıracak çözümler düşünülürken, optimal stok seviyesinin sağlanmasına yönelik planlar ve ödemelerin ertelenmesi yoluyla nakit elde etmeye yönelik girişimler finans yöneticilerinin uğraş alanı olmuştur. Artan kredi riski karşısında şirketlerin güvenli bir şekilde ticaretlerini sürdürülmeleri riski erken teşhis etme çabaları ile mümkündür. Ülke ve sektör risklerinin yeniden değerlendirilmesi, aynı ülkede veya aynı sektörde faaliyet gösteren alıııların kredi değerliliği arasındaki farkların kıyaslama yoluyla analiz edilmesi gerekmektedir. Gerçek zamanlı bilgiye ulaşma ve değerlendirmelerin gerçek zamanlı veriler üzerinden yapılması son derece önemli hale gelmiştir. Riskin şirket satışları ve karı üzerindeki muhtemel etkisinin ne olabileceği çeşitli senaryo analizleri ile modellenmelidir. Risk izlemeye yönelik faaliyetler şirketler için son derece kritik faaliyetler olarak öne çıkmaktadır. Tüm tedarik zinciri ekosisteminin genel refahının sağlanması, şirketlere bu dönemde sosyal sorumluluk da yüklemektedir. Şirketler sadece kendi alacak ve borç yönetimi faaliyetleriyle sınırlı olmayan aynı zamanda tedarikçilerini ve müşterilerini dikkate alan çözümleri düşünmek durumundadırlar. Bununla birlikte risk yönetimi sürdürülebilir ticaret yapmanın önkoşuludur.

\section{REFERANSLAR}

Becue, Paul. (2013). Credit Insurance. Leuven, Lanoo Campus Publishers.

Bragg, Steven.M. (2011) Accountant, Controllership:The Work of the Managerial Accountant. John Wiley \& Sons, Inc.

Çetiner, M., \& Eke, S. (2018). İhracat Artışının ve ekonomik büyümenin Sağlanmasına Yönelik Olarak İhracatta Tedarşkçi Kredi riskinin Sigortalanması. JEFA, journal of Economics , Finance and Accounting, 5(4), 359-372.

Çetiner, M., \& Eke, S. (2020). İhracatta Tedarikçi Kredi Riskinin Garanti Altına Alınmasında Faktoring, İhracat Artışına ve Ekonomik büyümeye Desteği. Finans, Ekonomi ve Sosyal Araştırmalar Dergisi, Cilt 5, Sayı 2 , 288-301.

Gordon, K. (2008). Investment Guarantees and Political Risk Insurance: Institutions, Incentives and Development. OECD Investment Policy Periodicals. Retrieved from https://www.oecd.org/finance/insurance/44230805.pdf

Holliwell, J. (1998). The Financial Risk Manual, A Systematic Guide to Identifying and Managing Financial Risk. Financial Times Prentice Hall. Kontus, Eleonora. (2013).Management of Accounts Receivable in a company. Ekonomska Misoo Praksa .

Lam, J. (2003). Enterprise Risk Management, From Incentives to Controls. U.S.A: Wiley Finance.

McKinsey \& Company (2020). Managing and Monitoring Credit Risk after Covid-19 Pandemic. Retrieved from https://www.mckinsey.com/business-functions/risk/our-insights/managing-and-monitoring-credit-risk-after-the-covid-19-pandemic

O'Connelly, P. (2007). Trade Credit Risk Management, Fundamentals of Craft in Theory and Practice. Florida : Library of Congress.

Bottoni, A. (2001). Handbook of International Credit Management. (B. Clarke, Ed.) Gower Publishing Limited

Bullivant, G. (2010). Credit Management (Vol. 6th Edition). London, U.K.: Gower Publishing.

Hopkin, P. (2017). Fundamentals of Risk Management. U.S.A: Kogan Page.

Joachim C Bartels, G. A. \& Geoffrey Hirt (2001). Handbook of International Credit Management (Vol. Third Edition). (B. W. Clarke, Ed.) Burlington, U.S.A: Gower Publishing Company.

Joseph, C. (2013). Advanced Credit Risk Analysis and Management. U.K: Wiley Finance.

Jus,Miranda. (2013). Credit Insurance. Elsevier Publications

Bouteille, Sylvain , Pushner,Diane Coogan. (2013). The Handbook of Credit Risk Management. New Jersey , U.S.A: John Wiley \& Sons, Inc.

Edwards, Burt (2010).Credit Management,Gower Publishing 
Berk, Prof.Dr.Niyazi (2000), Finansal Yönetim. İstanbul: Türkmen Kitapevi

Rejda, George E.; McNamara, Michael J.( 2017).Principles of Risk Management and Insurance. Essex, Pearson Education Limited.

Salek, John C.( 2005). Account Receivable Management, Best Practices. New Jersey, Wiley Best Practices.

2019 CPI Report. Retrieved from Transparency Internatonal: https://www.transparency.org/files/content/pages/2019 CPI Report EN.pdf

Allianz Global Corporate \& Specialty,. (2020). Retrieved from Business Interruption Insurance Trends:

https://www.agcs.allianz.com/solutions/business-interruption.html

Atradius Group. Retrieved from https://group.atradius.com/

Bribery Act 2010. Retrieved from https://www.legislation.gov.uk/ukpga/2010/23/contents

Coface Global, Retrieved from https://www.coface.com/

Compliance Case Studies.Retrieved from https://redflaggroup.com/category/type/case-studies/

CRIF. Retrieved from https://www.crif.com.tr/üruen-hizmetler/risk-yoenetimi-çoezuemleri/

EU Global Sanctions Guide. Retrieved from https://sanctionsguide.eversheds-sutherland.com/countries/the-european-union/

Euler Hermes. Retrieved from https://www.eulerhermes.com/en global/economic-research/country-reports/Turkey.htm/

Institute of Risk Management. (2020, Nov.28 ). Retrieved from A Risk Management Standard:

https://www.theirm.org/media/6827/arms 2002 irm.pdf

Kredi Kayit Burosu. Retrieved from https://www.kkb.com.tr/hakkimizda

OFAC Sanctions List. Retrieved from List https://home.treasury.gov/policy-issues/financial-sanctions/specially-designated-nationals-andblocked-persons-list-sdn-human-readable-lists

Refinitiv. Retrieved from https://www.refinitiv.com/en/about-us

Riestra, Ampra San Jose (2003) Retrieved from credit Insurance in Europe, Impact, Measures and Policy Recommendation: http://aei.pitt.edu/9563/2/9563.pdf

S\&P Global Market Intelligence (2020, July 24) Covid-19: Assessing Credit risk Impact on Small and medium Enterprises. Retrieved from https://www.spglobal.com/marketintelligence/en/news-insights/blog/covid-19-assessing-the-credit-risk-impact-on-small-and-mediumenterprises

The United States Department of Justice Foreign Corrupt Practices Act. Retrieved from https://www.justice.gov/criminal-fraud/foreigncorrupt-practices-act

SDN. Retrieved from https://sanctionssearch.ofac.treas.gov/

World Check KYC Screening. Retrieved from https://www.refinitiv.com/en/products/world-check-kyc-screening/customer-risk-screening 